\title{
Effects of Withdrawal from Cocaine Self- Administration on Rat Orbitofrontal Cortex Parvalbumin Neurons Expressing Cre recombinase: Sex-Dependent Changes in Neuronal Function and Unaltered Serotonin Signaling
}

\author{
Andrew M. Wright, ${ }^{1}$ Agustin Zapata, ${ }^{1}{ }^{\circledR}$ Alexander F. Hoffman, ${ }^{1}$ ○Julie C. Necarsulmer, ${ }^{2,3}$ \\ Lamarque M. Coke, ${ }^{2,3}$ Reinis Svarcbahs, ${ }^{2,3}$ Christopher T. Richie, ${ }^{3}$ James Pickel, ${ }^{5}{ }^{\circ}$ Bruce T. Hope, ${ }^{4}$ \\ ${ }^{-B}$ Brandon K. Harvey, ${ }^{2,3}$ and ${ }^{\circledR}$ Carl R. Lupica ${ }^{1}$
}

\author{
https://doi.org/10.1523/ENEURO.0017-21.2021
}

${ }^{1}$ Electrophysiology Research Section, Cellular Neurobiology Branch with: Cellular and Neurocomputational Systems Branch, ${ }^{2}$ Molecular Mechanisms of Cellular Stress and Inflammation Section, ${ }^{3}$ Optogenetics and Transgenic Technology Core, ${ }^{4}$ Neuronal Ensembles in Drug Addiction Section Integrative Neuroscience Branch, National Institute on Drug Abuse, Intramural Research Program, National Institutes of Health, Baltimore, MD 21224, and ${ }^{5}$ Transgenic Technology Core, Intramural Research Program, National Institute of Mental Health, Bethesda, MD 20892

\begin{abstract}
The orbitofrontal cortex (OFC) is a brain region involved in higher-order decision-making. Rodent studies show that cocaine self-administration (CSA) reduces OFC contribution to goal-directed behavior and behavioral strategies to avoid drug intake. This change in OFC function persists for many weeks after cocaine withdrawal, suggesting involvement in the process of addiction. The mechanisms underlying impaired OFC function by cocaine are not well-understood. However, studies implicate altered OFC serotonin (5-HT) function in disrupted cognitive processes during addiction and other psychiatric disorders. Thus, it is hypothesized that cocaine impairment of OFC function involves changes in 5-HT signaling, and previous work shows that 5- $\mathrm{HT}_{1 \mathrm{~A}}$ and 5$\mathrm{HT}_{2 \mathrm{~A}}$ receptor-mediated effects on OFC pyramidal neurons (PyNs) are impaired weeks after cocaine withdrawal. However, 5-HT effects on other contributors to OFC circuit function have not been fully investigated, including the parvalbumin-containing, fast-spiking interneurons $\left(\mathrm{OFC}^{\mathrm{PV}}\right)$, whose function is essential to normal OFC-mediated behavior. Here, 5-HT function in naive rats and those withdrawn from CSA were evaluated using a novel rat transgenic line in which the rat parvalbumin promoter drives Cre-recombinase expression to permit identification of OFC ${ }^{P V}$ cells by fluorescent reporter protein expression. We find that whereas CSA altered basal synaptic and membrane properties of the OFC ${ }^{P V}$ neurons in a sex-dependent manner, the effects of $5-\mathrm{HT}$ on these cells were unchanged by CSA. These data suggest that the behavioral effects of
\end{abstract}

\section{Significance Statement}

Cocaine addiction involves the inability to change behavior having negative consequences and the reluctance to adopt beneficial behaviors. The orbitofrontal cortex (OFC) is a brain region involved in this behavioral flexibility, and OFC function is impaired after cocaine use. Moreover, signaling by the neurotransmitter serotonin (5-HT) is impaired in OFC pyramidal neurons (PyNs) after cocaine. However, whether other types of OFC neurons are affected by cocaine is unknown, and we asked whether changes occur in another class of OFC cells known as parvalbumin interneurons. We report that cocaine changed the activity of parvalbumin interneurons in a sex-dependent manner but did not alter 5-HT effects. This suggests that the effects of cocaine on 5-HT function in OFC involves PyNs and not parvalbumin interneurons. 
dysregulated OFC 5-HT function caused by cocaine experience are primarily mediated by changes in $5-\mathrm{HT}$ signaling at PyNs, and not at OFC ${ }^{P V}$ neurons.

Key words: addiction; electrophysiology; orbitofrontal cortex; parvalbumin; self-administration; serotonin

\section{Introduction}

The orbitofrontal cortex (OFC), a prefrontal cortical (PFC) area, is a brain region involved in executive cognitive function in domains such as associative learning, reversal learning, outcome prediction, and estimation of reward value (Jones and Mishkin, 1972; Schoenbaum et al., 1998, 2016; Gallagher et al., 1999; Tremblay and Schultz, 1999; Izquierdo and Murray, 2004; Hardung et al., 2017). A hallmark of OFC function is its contribution to flexible behavior as defined by the ability to shift behavioral strategies in the face of changing contingencies and expected outcomes (Ostlund and Balleine, 2007; Schoenbaum and Esber, 2010; Gremel and Costa, 2013; Izquierdo, 2017).

The OFC is innervated by all major monoaminergic nuclei (Chandler et al., 2013) and sends projections to most of these areas (Dalley et al., 2004; Hoover and Vertes, 2011). Of relevance is the dense innervation the OFC receives from the 5-HT neurons of the dorsal raphe nucleus (Azmitia and Segal, 1978; Hornung et al., 1990; Wilson and Molliver, 1991a,b; Gonçalves et al., 2009; VázquezBorsetti et al., 2009; Roberts, 2011; Chandler et al., 2013). A growing body of evidence shows that $5-\mathrm{HT}$ is critical for OFC-dependent behavior and that dysregulation of $5-\mathrm{HT}$ function is implicated in psychiatric disorders where changes in OFC-dependent executive function are observed (Roberts, 2011). Additionally, pharmacologically targeting the $5-\mathrm{HT}$ system is associated with positive treatment outcomes and increased OFC metabolism in psychiatric disorders (Saxena et al., 1999; New et al., 2004). In animal studies, OFC-dependent behavioral tasks that require shifts in behavioral strategies to obtain reward are impaired by the depletion of 5-HT (Clarke et al., 2004; Roberts, 2011; Izquierdo et al., 2012; West et al., 2013). Moreover, selective ligand activation of 5-HT receptor subtypes within the OFC alters reversal learning, a form of behavioral flexibility (Boulougouris and Robbins, 2010; Furr et al., 2012), and other OFC-dependent

Received January 9, 2021; accepted May 20, 2021; First published June 1, 2021.

The authors declare no competing financial interests.

Author contributions: A.M.W., A.Z., C.T.R., J.P., B.T.H., B.K.H., and C.R.L. designed research; A.M.W., A.Z., A.F.H., J.C.N., L.M.C., R.S., and C.T.R. performed research; C.T.R., J.P., B.T.H., and B.K.H. contributed unpublished reagents/analytic tools; A.M.W., A.Z., A.F.H., J.C.N., L.M.C., R.S., C.T.R., B.T.H., B.K.H., and C.R.L. analyzed data; A.M.W., A.F.H., C.T.R., B.T.H., B.K.H., and C.R.L. wrote the paper.

This work supported by the National Institutes of Health, National Institute on Drug Abuse Intramural Research Program (IRP), and National Institute of Mental Health IRP.

Correspondence should be addressed to Carl R. Lupica at clupica@nih.gov. https://doi.org/10.1523/ENEURO.0017-21.2021 Copyright (C) 2021 Wright et al.

This is an open-access article distributed under the terms of the Creative Commons Attribution 4.0 International license, which permits unrestricted use, distribution and reproduction in any medium provided that the original work is properly attributed. behaviors such as reinforcer devaluation and response inhibition are blocked by lesions of OFC 5-HT axons (West et al., 2013; Man et al., 2010).

The inability to change behavior in the absence of reward or in the presence of aversive consequences is endemic to cocaine use disorder (CUD) in humans, and cocaine exposure is associated with the dysregulation of OFC function in humans and in animal models (Volkow and Fowler, 2000; Bechara, 2005; Schoenbaum and Shaham, 2008; Lucantonio et al., 2012, 2014; Simmler et al., 2017). Thus, CUD is associated with a reduction in OFC metabolic activity that persists after cocaine withdrawal (Volkow et al., 1993; Volkow and Fowler, 2000), and enduring impairments in performance of behavioral tasks relying on intact OFC function are observed in animals following cocaine withdrawal. This includes reductions in the ability to change strategies to obtain reward (e.g., reversal learning; Jentsch et al., 2002; Schoenbaum et al., 2004; Calu et al., 2007), and in performance of non-operant behaviors such as reinforcer devaluation (Schoenbaum and Setlow, 2005) and overexpectation learning (Takahashi et al., 2013; Lucantonio et al., 2014). These findings point toward longlasting changes in OFC function contributing to disordered behavior following cocaine exposure in humans and in animals (Lucantonio et al., 2014). However, the neural mechanisms through which this occurs are poorly understood.

The changes in OFC-dependent behavior observed after cocaine experience are hypothesized to result from altered serotonergic control of OFC neuron activity as large reductions in 5-HT-mediated electrophysiological effects and altered expression of $5-\mathrm{HT}_{2 \mathrm{~A}}$ receptor transcripts are observed in OFC pyramidal neurons (PyNs) weeks after withdrawal from cocaine self-administration (CSA) or yoked cocaine administration (Wright et al., 2017). However, the output of OFC, like other cortical circuits, relies on the interaction of glutamatergic PyNs (principal cells) with less-numerous local circuit GABAergic interneurons. One class of these interneurons, known as fast-spiking parvalbumin neurons (OFC ${ }^{P V}$ ), regulates PyN excitability via inhibitory synapses and plays an essential role in the generation of $\gamma$ oscillations that promote frontocortical synchrony necessary for OFC-dependent behavior (Bissonette et al., 2015). As cortical parvalbumin neurons also express 5 -HT receptors (Santana et al., 2004; Athilingam et al., 2017), and promote cortical synchrony (Puig et al., 2010), we hypothesize that withdrawal from CSA will also alter 5HT responses in these cells. To evaluate this, a novel transgenic rat (Pvalb-iCre) was developed in which Cre-recombinase expression was driven by the parvalbumin promoter, and a Cre-dependent viral targeting strategy was used to examine 5-HT function in these cells following withdrawal from CSA. We report that although sex-dependent differences in OFC ${ }^{P V}$ neuron properties were observed after CSA, and effects of 5$\mathrm{HT}$ on these cells differed between male and female 
cocaine-naive rats, no changes in response to 5-HT were observed after cocaine withdrawal. Therefore, we conclude that the enduring effects of cocaine on OFC 5-HT function and behavior likely occur primarily through actions at PyNs and not OFC ${ }^{\mathrm{PV}}$ cells.

\section{Materials and Methods}

\section{Generation of a bacterial artificial chromosome (BAC) for Pvalb-iCre}

A BAC carrying a 70-kb fragment of rat genomic DNA containing the Pvalb gene locus was obtained from the Children's Hospital Oakland Research Institute (CH230499N20). The BAC was transformed into the recombineering bacterial strain (GS1783) using electroporation and edited using "en passant mutagenesis" to replace the start codon of the Pvalb gene (Tischer et al., 2010; Shimshek et al., 2002). Specifically, a cassette containing an I-Scel restriction site and a KanS selection marker was amplified from pEP-KanS (a gift from Nikolaus Osterrieder; Addgene plasmid \#41017; http://n2t.net/ addgene:41017; RRID:Addgene_41017) and inserted into a plasmid containing the coding region for iCre (pBS mFos TetO iCre, pOTTC161). A 50-bp portion of the iCre coding region was duplicated on both sides of the insertion to facilitate intramolecular recombination and marker removal in subsequent steps. The final plasmid, pBS mFos TetO iCre(KanS) (pOTTC4094) was used as a template to PCR amplify the entire iCre-(I-Scel-KanS) coding region with primers appended with $5^{\prime}$ linkers corresponding to $50 \mathrm{bp}$ of homology with the sequences adjacent to the Pvalb start codon. This PCR product was electroporated into the GS1783 cells containing the Pvalb BAC after heat shock, and the transformants were selected on LB agar plates containing chloramphenicol and kanamycin. Successful transformants were screened by PCR across the $5^{\prime}$ and $3^{\prime}$ junctions and sequence verified for error-free insertion. The kanamycin resistance marker was removed, and the iCre coding region restored by the simultaneous treatment with arabinose and heat shock. Cultures were diluted and streaked onto plates containing LB agar plates containing chloramphenicol. Successful recombinants were screened by PCR and verified by sequencing and pulse-field agarose gel electrophoresis. The final Pvalb-iCre BAC (pOTTC465) was prepped using Macherey-Nagel NucleoBond Xtra BAC columns and then used to create the transgenic rat line. See schematic of final transgene (Fig. 1, transgene and characterization).

\section{Transgenic rat husbandry}

All animal procedures were performed in accordance with National Institutes of Health Animal Care Guidelines and approved by local animal care and use committees. Procedures were initially based on those for optimizing the production of transgenic rats (Filipiak and Saunders, 2006) with modifications described here. Female LongEvans rats purchased from Charles River Laboratories and maintained in a 6 A.M. to 6 P.M. light cycle with food and water ad lib were superovulated and mated as described (Filipiak and Saunders, 2006). Briefly, the ovulation of females, four to five weeks of age, was synchronized using 40- $\mu \mathrm{g}$ LHRH (Luteinizing Hormone Releasing Hormone, Sigma Chemicals) injected intraperitoneally on day 1 . Superovulation was achieved with $20 \mathrm{IU}$ pregnant mare serum gonadotropin (PMSG; National Hormone and Peptide Program) $48 \mathrm{~h}$ later at 10 A.M. Another $48 \mathrm{~h}$ later, $20 \mathrm{IU}$ human chorionic gonadotropin (hCG; Novarel, Ferring) was injected intraperitoneally. Directly after these injections the females were added to cages with singly housed Long-Evans stud males. The next morning at 9 A.M. copulation plugs were identified, and fertilized oocytes collected from the females in M2 medium and then treated with $\mathrm{M} 2$ /hyaluronidase to remove cumulus cells. They were then transferred to KSOM medium (all medium from Sigma) and incubated at $37^{\circ}$ with $5 \% \mathrm{CO}_{2}$ in a humidified incubator. By 10 A.M. when pronuclear membranes were visible, they were injected with a solution (2$3 \mathrm{ng} / \mu \mathrm{l})$ of the BAC DNA described above. Later in the day zygotes were surgically transferred to the oviducts of female rats. These recipients and vasectomized males were housed in a 3 A.M. to 3 P.M. light cycle. The females' ovulation synchronized as described above with $80 \mu \mathrm{L} \mathrm{LHRH}$ on day 1 at 10 A.M. and mated with vasectomized SD males on day 5 . These recipient females were monitored daily after surgery. Pups were weaned at p21 and ear punches were used to identify and provide biopsies for genotyping as described below. Animals found to be positive for the transgene were then identified with ear tags. Animals were bred as Cre-positive carriers by wild-type Long-Evans from Charles River Laboratories.

\section{Genotyping and copy number analysis}

Genomic DNA was isolated from tissue biopsies or primary cells using a Macherey-Nagel Tissue Spin kit. Two genotyping protocols were used to identify animals carrying the Pvalb-iCre transgene. The $5^{\prime}$ junction was amplified with Pvalb F16505 (5'-CAGAACTCTCCAGTGTCT GCTGG-3') and iCre R173 (5'-CTTCCAGGTGTGTT CAGAGAAG-3') to produce a 476-bp amplicon. The $3^{\prime}$ junction was amplified with iCre F738 (5'-GTTCTGCCG GGTCAGAAAGAATGGT-3') and Pvalb R16998 (5'-CCAA CCCCGAGGATAAGGGAATG-3') to produce a 713-bp amplicon. All PCRs used OneTaq (New England Biolabs), and 40 cycles of $94^{\circ} \mathrm{C}$ for $30 \mathrm{~s}$ and $68^{\circ} \mathrm{C}$ for $1 \mathrm{~min}$. Amplification products were analyzed by agarose gel electrophoresis. For copy number determination, the genomic DNA was isolated as described above served as template for droplet digital PCR using ddPCR Supermix for Probes (No dUTP; Bio-Rad \#1863024) and FAM-labeled or HEX-labeled probe assays for reference gene Ggt1 (Witten et al., 2011) and iCre (Table 1). Droplets were generated and analyzed using a QX200 AutoDG Droplet Digital PCR System (Bio-Rad). Amplification reactions were run in a Bio-Rad T100 thermocycler.

\section{Histologic analysis of brains}

\section{Cre-dependent AAV reporters for initial phenotyping of} putative lines

Parvalbumin-iCre rats used in the present experiments were injected with Cre-dependent fluorescent reporters 


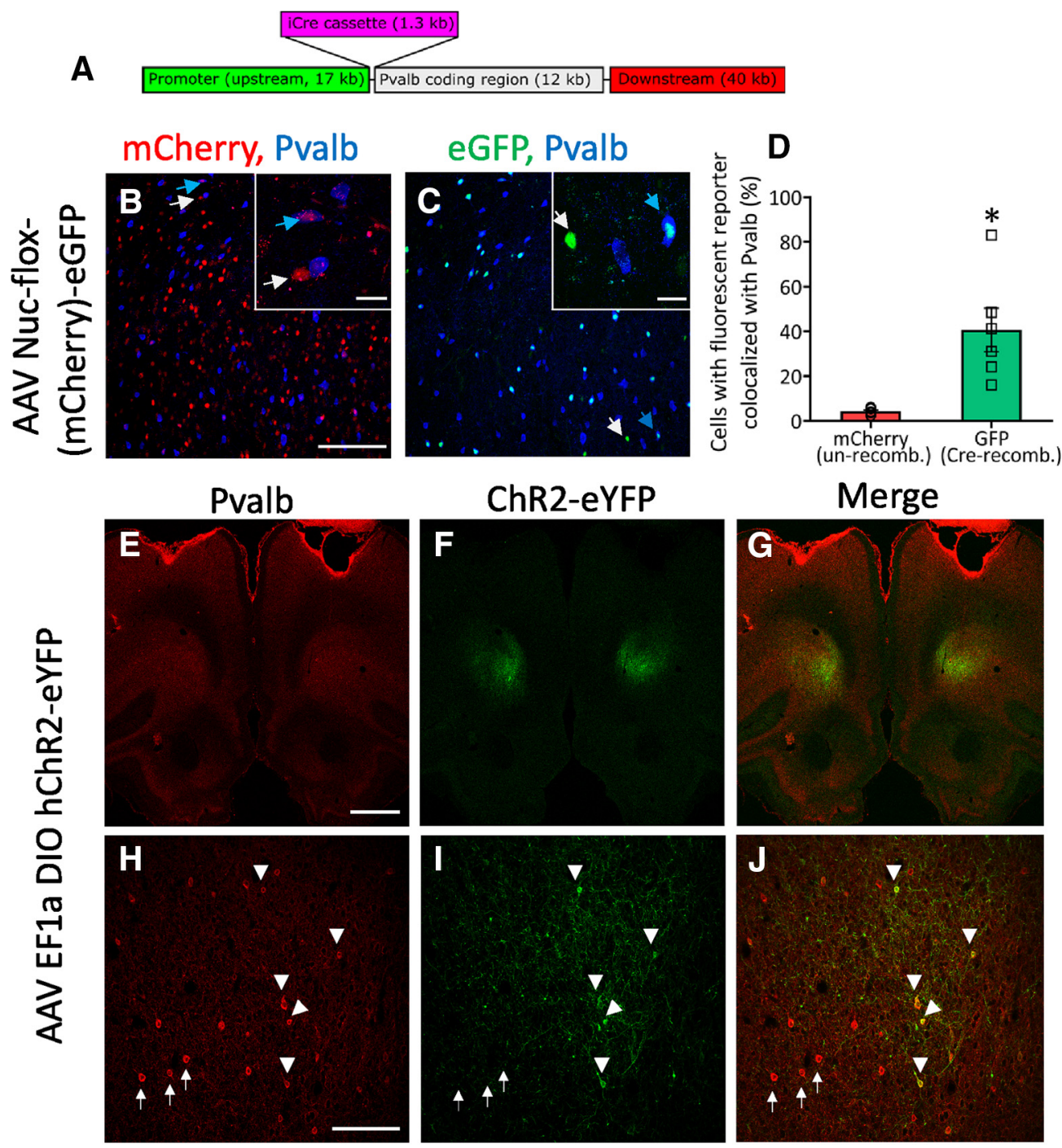

Figure 1. Generation of Pvalb-Cre rats. A, Schematic of the Pvalb-iCre transgene produced by recombineering BAC CH230499N20 which contains $17 \mathrm{~kb}$ of endogenous sequence upstream of the Pvalb start codon. Pvalb-iCre rats were injected bilaterally with AAV Nuc-flox-(mCherry)-eGFP into the OFC and brains processed for fluorescent imaging four weeks later. $\boldsymbol{B}$, Unrecombined AAV genomes express mCherry in the OFC (red) and have minimal colocalization with Pvalb-positive cells (blue). Inset shows high magnification of a mCherry+, Pvalb + cell (blue arrow), and a mCherry+, Pvalb- cell (white arrow). C, Cre-recombination leads to GFP-positive cells (Cre recombined; green) which showed colocalization with Pvalb (blue). Inset is high magnification example of a GFP+, Pvalb + cell (blue arrow) and a GFP+, Pvalb- cell (white arrow). D, Quantitation of colocalization of mCherry (unrecombined) and GFP (Cre-recombined) with Pvalb-positive cells. ${ }^{*} p=0.038$, paired t-test. $\boldsymbol{E}-\boldsymbol{J}$, Rats were injected with AAV EF1a DIO hChR2eYFP and immunostained for parvalbumin $20 \mathrm{~d}$ later. At low magnifications, diffuse Pvalb-immunoreactivity $(\boldsymbol{E})$ and focal ChR2EYFP $(\boldsymbol{F})$ expression in the OFC. At higher magnification, distinct Pvalb-immunopositive cells are present in OFC $(\boldsymbol{H})$ and a meshlike pattern of fluorescence from ChR2-EYFP expressed throughout cell bodies and processes in the OFC (II). In cells clearly exhibiting somal expression of ChR2-EYFP (white triangle), there is corresponding expression of Pvalb ( $\boldsymbol{J}$ ). Pvalb-positive cells that do not colocalize with ChR2-EYFP are indicated white arrow). Scale bars: $50 \mu \mathrm{m}(\boldsymbol{B}, \boldsymbol{C}, \boldsymbol{H}, \boldsymbol{J}), 20 \mu \mathrm{m}$ (inset), and $1000 \mu \mathrm{m}(\boldsymbol{E}-\boldsymbol{G})$.

Table 1: Primers and probes for droplet digital PCR for quantification of copy number

\begin{tabular}{lll}
\hline Primer name & Primer Seq & Target gene \\
\hline Ggt1 probe (HEX, IBFQ) & CCGAGAAGCAGCCACAGCCATACCT & Ggt1 \\
Ggt1pF & CCACCCCTTCCCTACTCCTAC & Ggt1 \\
Ggt1pR & GGCCACAGAGCTGGTTGTC & Ggt1 \\
iCrepF & ATGGTGCCCAAGAAGAAGAG & iCre \\
iCre probe (FAM, IBFQ) & AAGTCTCCAACCTGCTGACTGTGC & iCre \\
iCrepR & CTTCCTGACTTCATCAGAGGTG & iCre \\
\hline
\end{tabular}


to identify Cre recombination present in the OFC and other brain regions. For example, an AAV vector expressing a nuclear-localized, color-changing reporter, AAV Nuc-flox-(mCherry)-eGFP (Bäck et al., 2019) was injected into OFC and four weeks later the brains were processed for fluorescent protein expression. To fix brain tissue, animals were anesthetized using isoflurane, then transcardially perfused with heparinized PBS, followed by $4 \%$ paraformaldehyde (PFA), and then postfixed for $2 \mathrm{~h}$ in $4 \%$ PFA. Extracted brains were immersed in succeeding gradients of $18 \%$ to $30 \%$ sucrose for cryopreservation before being flash frozen. Brains were cryosectioned at $30 \mu \mathrm{m}$ and washed for $30 \mathrm{~min}$ in PBS, followed by a 1-h incubation in a $4 \%$ goat serum $0.3 \%$ Triton X-100 blocking solution. After 30 min of washing, sections were incubated in primary antibody in blocking solution (mouse anti-parvalbumin, 1:1000, Sigma, P3088) overnight, shaking at $4^{\circ} \mathrm{C}$. Sections were then washed in $3 \times$ in PBS, incubated for 1 $\mathrm{h}$ in a secondary antibody blocking solution (goat antimouse, 1:500, Alexa Fluor 680, Invitrogen, A21058) and washed again in PBS. Sections were then stained with DAPI and imaged at $20 \times$ magnification using laser confocal microscopy (Nikon Eclipse E800 microscope body, Nikon C2 Confocal microscope system, NIS-Elements imaging software version 4.40; Nikon Instruments Inc.). Cell counting and quantification of parvalbumin and redto-green signal colocalization was performed in six rats (three males, three females). Six representative brain sections from each animal were used for quantification (ImageJ 1.53C). For single channel quantification, automatic cell counting of particles larger than $3 \mu \mathrm{m}$ in diameter was applied after adjusting for the background. For colocalization, manual counts were performed. Data are presented as mean \% ( \pm SEM) of red or green cells colocalized with parvalbumin staining.

\section{Channelrhodopsin2 (hChR2) and endogenous Pvalb expression}

For examining colocalization of hChR2 expression with OFC Pval+ neurons, parvalbumin-iCre rats Line 2 were euthanized $20 \mathrm{~d}$ following bilateral injection of AAV5EF1 $\alpha$-DIO-hChR2(H134R)-EYFP (Addgene) into the OFC for immunohistochemical analysis. Brains were collected and sectioned as described above. For immunolabelling, $30-\mu \mathrm{m}$ cryosections were washed for $30 \mathrm{~min}$ in $1 \times$ PBS, followed by a 1 -h incubation in a $4 \%$ goat serum $0.3 \%$ Triton X-100 blocking solution. After $30 \mathrm{~min}$ of washing, sections were incubated in primary antibody in blocking solution (mouse anti-parvalbumin, 1:1000, Sigma, P3088) overnight, shaking at $4^{\circ} \mathrm{C}$. Sections were then washed in $1 \times$ PBS, incubated for $1 \mathrm{~h}$ in a secondary antibody blocking solution (goat anti-mouse, 1:500, Alexa Fluor 568, Invitrogen, A11004), and washed again in $1 \times$ PBS. Sections were then stained with DAPI and imaged using confocal microscopy as described above.

\section{Subjects}

All experimental procedures were approved by the local animal care and use committee and housed in facilities certified by the American Association for the
Accreditation of Laboratory Animal Care (AAALAC). Male and Female Pvalb-iCre rats (generated as described above), $140-300 \mathrm{~d}$ of age at the time of electrophysiological recording, were housed two to three per cage for at least one week before experimental procedures. They were maintained in a temperature-controlled and humidity-controlled environment under a reverse 12/12 h light/dark cycle (lights on at 9P.M., lights off at 9 A.M.) with food and water available ad libitum. All behavioral experiments were run during the dark phase of the light cycle and begun each day between 10 and 12 A.M. For animals in CSA groups, one week following intravenous catheterization surgery food was restricted to $15 \mathrm{~g}$ of standard rodent diet per day and made available after the daily CSA sessions. Animals were food restricted until the end of self-administration training, after which ad libitum feeding resumed. All behavioral experiments were conducted during the dark cycle.

\section{Surgery \\ Intracranial surgery}

Rats were anesthetized with isoflurane (3\% concentration at $1.5 \mathrm{I}$ of $100 \% \mathrm{O}_{2} / \mathrm{min}$ for induction, $2.5 \%$ at $1.5 \mathrm{I} /$ min for maintenance) which was applied with a Parkland Scientific V300PK Anesthesia Machine and maintained using a Somni EPS-3 Exposure Prevention System (Somni Scientific). Small holes were drilled into the skull and a stainless-steel cannula was positioned using the coordinates; $+4.0 \mathrm{~mm}$ anterior to bregma, $2.0 \mathrm{~mm}$ lateral to the midline skull suture, and ventral $-3.3 \mathrm{~mm}$ from the brain surface using a stereotaxic apparatus (Stoelting). Bilateral Injections of the ChR2 viral construct (AAV5-EF1 $\alpha$ DIO-hChR2(H134R)-EYFP, titer $1.8 \times 10^{13}$, Addgene), at a volume of $700 \mathrm{nl}$, were performed using a Hamilton $1-\mu \mathrm{l}$ syringe at a rate of $150 \mathrm{nl} / \mathrm{min}$. Following surgery, rats were given one injection of 4-hydroxy-2-methyl- N-(5-methyl2-thiazolyl)-2H-1,2-benzothiazine-3-216 carboxamide-1,1dioxide (Meloxicam, $5 \mathrm{mg} / \mathrm{mL}$, Boehringer/Ingelheim, Ingelheim, FRG) for post-surgical analgesia, and then single housed with ad libitum access to food. The animals were then returned to their home cages and at least two to three weeks were permitted for full expression of the viral construct.

\section{Intravenous self-administration (IVSA) surgery}

Rats were anesthetized with equithesin (1\% pentobarbital, $2 \%$ magnesium sulfate, $4 \%$ chloral hydrate, $42 \%$ propylene glycol, $11 \%$ ethanol, $3 \mathrm{ml} / \mathrm{kg}$, i.p.), and a SILASTIC catheter (inner diameter, 0.020 inch; outer diameter, 0.037 inch; Dow Corning) was advanced $3.5 \mathrm{~cm}$ into the right jugular vein and secured with silk suture (5$0)$. Anesthetic depth was assessed continuously throughout the procedure. The catheter terminated in a modified L-shaped 22-G guide cannula (Plastics One) mounted on the skull with cranioplastic cement and secured with three stainless steel screws. Animals were given one injection of meloxicam; for postsurgical analgesia, and were single housed for the remainder of the experiment. Catheters were flushed daily with $0.1 \mathrm{ml}$ of heparinized saline, to 
maintain patency, and with cefazolin to forestall infection, until the end of operant training. Animals recovered for at least one week after the surgery, and before food restriction commenced. Postsurgery, all animals were monitored for $3 \mathrm{~d}$ for signs of adynamic ileus; no such signs were observed in any subjects. Operant training started 2-3 $d$ after the beginning of food restriction.

\section{CSA training}

Self-administration training took place in standard rat operant chambers equipped with two retractable levers (Med Associates). Each chamber was located in a sound attenuating enclosure, equipped with a ventilation fan that provided background noise. Catheters were connected to a length of metal coil-protected plastic tubing (Plastics One) via a liquid swivel (Instech) to a syringe mounted in an infusion pump (Med Associates) located outside the sound attenuating enclosure. Animals were trained to press one lever (active lever) for intravenous cocaine infusions under a fixed ratio 1 (FR1) schedule. At the beginning of the session, the two levers were inserted into the chamber and a house light located on the wall opposite the levers was illuminated. Each lever press resulted in infusion of $0.75 \mathrm{mg} / \mathrm{kg}$ cocaine $(2.25 \mathrm{mg} / \mathrm{ml}$ in sterile saline) accompanied by retraction of both levers, extinction of the house light and illumination of a cue light above the active lever for $30 \mathrm{~s}$. Responses on the inactive lever had no consequence. To facilitate acquisition of the response, animals were allowed to self-administer during 6-h sessions until they received 40 infusions within a session. Most of the animals acquired self-administration within one to two sessions. After that, sessions were limited to $3 \mathrm{~h}$ or 75 infusions, whichever occurred first. CSA under the FR1 schedule continued for a total of 12 daily sessions. Following behavioral training, rats in the CSA group remained single housed in their home cages, with ad libitum food and water available, until electrophysiology experiments.

\section{Brain slice preparation}

Animals were anesthetized with isoflurane and decapitated using a guillotine. The brains were then extracted and transferred to ice-cold NMDG cutting solution $(93 \mathrm{~mm}$ NMDG, $2.5 \mathrm{~mm} \mathrm{KCl,} 1.2 \mathrm{~mm} \mathrm{NaH}_{2} \mathrm{PO}_{4}, 30 \mathrm{~mm} \mathrm{NaHCO}, 20$ mM HEPES, 25 mm glucose, $5 \mathrm{~mm}$ ascorbic acid, $3 \mathrm{~mm}$ sodium pyruvate, $10 \mathrm{~mm} \mathrm{MgCl}_{2}$, and $0.5 \mathrm{~mm} \mathrm{CaCl}_{2}$ ). The tissue was then cut perpendicular to its longitudinal axis at $\sim 1.4 \mathrm{~mm}$ posterior to bregma using a razor blade, and then the sectioned surface was glued to the stage of a vibrating tissue slicer (Leica VT1200S, Leica Biosystems). Six to seven coronal sections $(250 \mu \mathrm{m})$ were collected from each brain beginning at the appearance of the dorsolateral orbital cortex and the rhinal fissure $(4.7 \mathrm{~mm}$ anterior to bregma) and ending at $\sim 3.2 \mathrm{~mm}$ anterior to bregma. For each animal, recordings were restricted to brain slices corresponding to these landmarks. The slices were then hemisected and transferred to heated $\left(34^{\circ} \mathrm{C}\right)$ NMDG for $5 \mathrm{~min}$. The brain slices were then transferred to an oxygenated $\left(95 \% \mathrm{O}_{2} / 5 \% \mathrm{CO}_{2}\right)$ holding chamber filled with HEPES-containing artificial CSF (aCSF; $109 \mathrm{~mm}$ $\mathrm{NaCl}, 4.5 \mathrm{~mm} \mathrm{KCl}, 1.2 \mathrm{~mm} \mathrm{NaH}_{2} \mathrm{PO}_{4}, 35 \mathrm{~mm} \mathrm{NaHCO}_{3}, 20$ mM HEPES, $11 \mathrm{~mm}$ glucose, $0.4 \mathrm{~mm}$ ascorbic acid, $1 \mathrm{~mm}$ $\mathrm{MgCl}_{2}$, and $\left.2.5 \mathrm{mM} \mathrm{CaCl}_{2}\right)$ at room temperature $\left(23^{\circ} \mathrm{C}\right)$ for at least $30 \mathrm{~min}$, and up to $7 \mathrm{~h}$.

\section{In vitro electrophysiology}

Hemisectioned slices were transferred to a chamber (RC-26; Warner Instruments) mounted to a fixed stage on a vibration isolation table (TMC Vibration Control). Slices were continuously perfused $(3 \mathrm{ml} / \mathrm{min})$ with oxygenated aCSF (126 mm NaCl, $3 \mathrm{~mm} \mathrm{KCl,} 1.2 \mathrm{~mm} \mathrm{NaH}_{2} \mathrm{PO}_{4}, 26 \mathrm{~mm}$ $\mathrm{NaHCO}_{3}, 11 \mathrm{~mm}$ glucose, $1.5 \mathrm{~mm} \mathrm{MgCl}$, and $2.4 \mathrm{~mm}$ $\mathrm{CaCl}_{2}$ using a peristaltic pump; Cole-Parmer), and warmed to $30-32^{\circ} \mathrm{C}$ using an in-line solution heater (Warner Instruments). The identification of OFC ${ }^{P V}$ neurons in layer $\mathrm{V}$ of the ventrolateral OFC was achieved through excitation of the virally expressed enhanced yellow fluorescent protein (eYFP), using light from a mercury lamp (X-Cite 120Q, Excelitas) directed through the objective of an upright microscope (BX51WI, Olympus) mounted on a motorized moveable stage. The microscope was also equipped with differential interference contrast (DIC) optics, and a 900-nm infrared light source to identify living neurons in brain slices containing the OFC.

Whole-cell recording electrodes were fabricated using borosilicate pipette glass (Sutter Instruments, $1.5 \mathrm{~mm}$ O. D. $\times 0.86 \mathrm{~mm}$ I.D.) and a horizontal puller (P-97; Sutter Instruments). They were filled with a potassium-based internal solution (140 mM K-gluconate, $5 \mathrm{~mm} \mathrm{KCl,} 10 \mathrm{~mm}$ HEPES, 0.2 mm EGTA, 2 mm $\mathrm{MgCl}_{2}$, 4 mм Mg-ATP, 0.3 $\mathrm{mm} \mathrm{Na} \mathrm{N}_{2}$-GTP, and $10 \mathrm{~mm} \mathrm{Na} \mathrm{Na}_{2}$-phosphocreatine), neutralized to a pH of 7.2 using potassium hydroxide. Electrode resistances were $3-7 \mathrm{M} \Omega$ when filled with this solution. Wholecell patch clamp recordings were performed using an Molecular Devices 700B Multi-Clamp amplifier (Molecular Devices). Depending on the experiment, cells were voltage clamped between -50 and $-65 \mathrm{mV}$. Spontaneous EPSCs (sEPSCs) were recorded in the presence of picrotoxin (50 $\mu \mathrm{M})$ to block $\mathrm{GABA}_{\mathrm{A}}$ receptor currents and sampled at $10 \mathrm{kHz}$ using WinLTP software (WinLTP Ltd) and an A/D board (National Instruments, PCl-6251) housed in a personal computer. Analyses of sEPSCs were performed offline and automated using the MiniAnalysis program (v 6.0.7, Synaptosoft). The sEPSC detection parameters were as follows: amplitude threshold, $5 \mathrm{pA}$; period to search for peak, $10,000 \mu \mathrm{s} ;$ necessary baseline before peak, $5000 \mu \mathrm{s}$; period for decay, 20,000 $\mu \mathrm{s}$; fraction of peak to find decay, 0.37 ; period of averaged baseline, $1000 \mu$ s; area threshold trigger, $20 \mathrm{pA} / \mathrm{ms}$. Peak detection valence was 'negative', and all detected events were visually inspected to verify analysis. An examination data from randomly sampled SEPSC recordings indicated that RMS noise ranged from 1.86 to $2.88 \mathrm{pA}$, with a mean $( \pm \mathrm{SEM})$ of $2.49 \pm 0.88 \mathrm{pA}(n=9)$. This indicates adequate sensitivity to resolve SEPSCs above the 5-pA threshold. This same sample of cells showed a sEPSC mean $50 \%$ rise time of $0.33 \pm 0.12 \mathrm{~ms}$, and a $37 \%$ decay time of $0.97 \pm 0.34 \mathrm{~ms}$. Hyperpolarizing voltage steps $(-10 \mathrm{mV})$ were delivered via the recording electrode every 
30 s to monitor whole-cell access and series resistance. Cells with an access resistance change of $>30 \%$ were excluded from analysis. Current clamp experiments were performed with depolarizing currents ranging from -30 to $600 \mathrm{pA}$. ChR2 stimulation was achieved with blue laser light $(473 \mathrm{~nm} ; 50 \mathrm{~mW}$ laser, OEM) collimated through the objective using an IS-OGP adapter (Siskyou Corp.). Serotonin (5-HT, $1 \mathrm{~mm}$; Tocris), was prepared fresh each day at low $\mathrm{pH}(\sim 2)$ to prevent oxidation and diluted 1:50 in aCSF flowing into the slice chamber, to achieve a final bath concentration of $20 \mu \mathrm{m}$ using a syringe pump (Model A-99, Razel Scientific Instruments). All other drugs were dissolved at their final concentration in aCSF and delivered using the peristaltic pump. Light-evoked (optical) IPSCs (oIPSCs) were recorded in the presence of 6,7-dinitroquinoxaline-2,3-dione (DNQX; $20 \mu \mathrm{m}$ ) to block glutamatergic synaptic currents.

\section{Statistical analyses}

Male and female Pvalb-iCre rats were randomly assigned to naive or CSA groups after intra-OFC injection of AAV5-EF1 $\alpha$-DIO-hChR2(H134R)-EYFP and recovery from this surgery. Formal experimenter blinding procedures were not used. However, complete analysis of the data and statistical comparisons from naive and CSA groups were not performed until data were collected from all subjects. Two rats were excluded from the studies, one because of the loss of intravenous catheter patency, the other died from an unknown cause during training. All experiments were designed using estimates of effect size and dispersion obtained from experience with similar OFC brain slice preparations. These estimates were then entered into power analysis calculations using G-Power (version 3.1.9.7, University of Dusseldorf, Germany) to ensure sample sizes were within reasonable estimates. In instances where experimental variability was large, additional experiments were performed. As stated above, recording from neurons exhibiting a change in access resistance (monitored continuously throughout the experiment) $>30 \%$ were ceased and the data discarded. The proportion of cells discarded for this reason is estimated to be not $>15 \%$. Graphing and statistical analyses were performed using GraphPad Prism (v9.2). Data are generally reported as mean \pm SEM or mean $\pm 95 \%$ confidence interval $(\mathrm{Cl})$, unless otherwise stated. Table 2 summarizes all statistical data, including tests of normality, significance levels, mean effect sizes, 95\% Cls, and post hoc results (Tukey's post hoc multiple comparisons test) for each experiment. Statistical tests included ANOVA [one-way, two-way, with repeated measures (RM) where appropriate], and the Student's $t$ test. The Fisher's exact test was used to determine proportional effect changes among neurons from naive and CSA rats. A minimum level of $p<0.05$ was considered to be significant in all statistical tests. Throughout, the number of rats from which data were acquired is indicated by $N$, whereas the number of cells is indicated by $n$.

\section{Results}

\section{Generation of transgenic rats and their characterization}

A BAC DNA containing the rat Pvalb coding region was successfully recombineered to contain iCre at the start codon of the Pvalb coding sequence (Fig. 1A). The resulting BAC was injected into rat embryos and resulted in three founder lines. One founder line did not propagate. Phenotyping animals from the other two lines was conducted by Cre-mediated recombination of an AAV vector expressing a nuclear-localized, color-changing reporter, AAV-Nuc-flox-(mCherry)-eGFP (Bäck et al., 2019). Line 2 exhibited Cre-recombination in the OFC (Fig. 1B-D). The number of mCherry-positive cells (no recombination) was clearly higher than the sparse number of eGFPpositive cells (Cre recombination). Quantification revealed the percentage of eGFP-positive cells coexpressing parvalbumin was variable but much higher than cells coexpressing mCherry and parvalbumin (Fig. 1D). The lack of parvalbumin immunoreactivity in some eGFP expressing cells may be because of fluctuations in parvalbumin expression, and therefore Cre, relative to when the injection occurred. The ability to colocalize parvalbumin signal with nuclear fluorescent signal may also be a limiting factor. Importantly, cells that showed no signs of recombination (mCherry positive cells) consistently showed minimal overlap with parvalbumin expression (Fig. 1B,D). Using AAV with Cre-dependent reporters in this manner, we followed several potential sublines over 3-4 generations showing Cre-recombination in areas where Pvalb is known to be expressed, such as prefrontal and somatosensory cortices, with a focus on the OFC. We also observed a subset of neurons in both somatosensory cortex and non-dopaminergic neurons in the midbrain that exhibited Cre activity. Moreover, another laboratory characterizing this same line of rats found that $98 \%$ of cells expressing a Cre-dependent eYFP in the amygdala also expressed parvalbumin immunoreactivity (unpublished observation; Gavan McNally, personal communication). Using another Cre-dependent, AAV vector expressing a translational fusion of the rhodopsin ion channel to eYFP (AAV-DIO- hChR2-eYFP), we also examined colocalization with endogenous Pvalb expression in the OFC (Fig. 1E-J). Cells with somal expression of ChR2-eYFP colocalized with Pvalb immunofluorescence. The cellular pattern of Pvalb-immunofluorescence was similar between ChR2-eYFP-positive cells at the injection sight and ChR2-eYFP-negative cells distal to the site of AAV-DIO-hChR2-eYFP injection indicating the transgene expression did not alter Pvalb expression. As with our injection of the AAV Nuc flox (mCherry) eGFP, we noted cells expressing hChR2-eYFP but not Pvalb, suggesting the presence of low level non-specific Cre expression or that the hChR2-eYFP expressing cells were no longer producing Pvalb at the time of tissue collection. Other brain regions were not extensively characterized in this line of transgenic rats, and any Cre-dependent transgene of interest should be empirically evaluated for a given brain area and testing 
Table 2: Statistical summary and analysis methods

\begin{tabular}{|c|c|c|c|c|c|c|c|c|c|c|c|c|}
\hline Figure reported & $\begin{array}{l}N, \\
\# \text { rats }\end{array}$ & $\begin{array}{l}n, \\
\# \text { cells }\end{array}$ & $\begin{array}{l}\text { Norm. } \\
\text { dist?* }\end{array}$ & Statistic & $\begin{array}{l}\text { Statistic } \\
\text { value } \\
\text { (df) }\end{array}$ & $p$ value & $\begin{array}{l}\text { Variance } \\
\text { source }\end{array}$ & $\begin{array}{l}\text { Post hoc } \\
\text { test }\end{array}$ & Post hoc $p$ & $\begin{array}{l}\text { Mean } \\
\text { difference }\end{array}$ & $\begin{array}{l}\text { Lower } \\
95 \% \mathrm{Cl}\end{array}$ & $\begin{array}{l}\text { Upper } \\
95 \% \mathrm{Cl} \\
\end{array}$ \\
\hline $1 D$, mCherry vs GFP & 6 & $\mathrm{~N} / \mathrm{A}$ & N/A & Unpaired $t$ test & $t_{(10)}=3.75$ & 0.0038 & Difference & & & 36.4 & 14.75 & 58.04 \\
\hline $\begin{array}{l}3 A, \text { eYFP vs No } \\
\text { eYFP (current in- } \\
\text { ject vs eYFP) }\end{array}$ & 11 & 23 & Yes & Two-way RM-ANOVA & $F_{(11,231)}=30.23$ & $<0.0001$ & Interaction & & & 55.91 & 34.80 & 77.00 \\
\hline $\begin{array}{c}3 A, \text { eYFP + vs eYFP } \\
\text { (current inject) }\end{array}$ & 11 & 23 & Yes & Two-way RM-ANOVA & $F_{(11,231)}=51.63$ & $<0.0001$ & Main effect & & & & & \\
\hline $\begin{array}{l}\text { 3A, eYFP + vs eYFP } \\
\quad(\text { eYFP) }\end{array}$ & 11 & 23 & Yes & Two-way RM-ANOVA & $F_{(1,21)}=17.61$ & 0.00040 & Main effect & & & & & \\
\hline $\begin{array}{l}3 D, \text { eYFP + vs eYFP } \\
\text { (max current) }\end{array}$ & 4 & 15 & Yes & Unpaired $t$ test & $t_{(22)}=5.804$ & $<0.0001$ & Difference & & & 82.03 & 55.61 & 108.50 \\
\hline $4 B$, control & 6 & 14 & Yes & & & & & & & & & \\
\hline $4 B$, gabazine & 6 & 14 & Yes & Paired $t$ test & $t_{(13)}=6.485$ & $<0.0001$ & Difference & & & -101.90 & -135.80 & -67.95 \\
\hline $\begin{array}{l}5 A, \mathrm{R}_{\text {in }} \text { (data not } \\
\quad \text { shown }\end{array}$ & 11 & 28 & Yes & Unpaired $t$ test & $t_{(21)}=1.25$ & 0.2250 & Difference & & & 102.60 & 98.25 & 107.00 \\
\hline $5 A, B$, control & 11 & 22 & & Unpaired $t$ test & $t_{(80)}=0.38$ & 0.0970 & Difference & & & -0.104 & -5.46 & 5.25 \\
\hline $5 C$, outward I & 11 & 4 & & One-sample test & $t_{(40)}=7.94$ & $<0.0001$ & Difference & & & 9.20 & 6.86 & 11.50 \\
\hline $\begin{array}{l}5 D \text {, ketanserin, male } \\
\quad \text { vs female }\end{array}$ & 8 & 16 & Yes & Two-way ANOVA & $F_{(1,27)}=8.671$ & 0.0066 & Interaction & & & & & \\
\hline $\begin{array}{l}5 D \text {, ketanserin, male } \\
\quad \text { vs female }\end{array}$ & 8 & 16 & & Two-way ANOVA & $F_{(1,27)}=8.135$ & 0.0082 & Main effect (sex) & & & & & \\
\hline $\begin{array}{l}5 D \text {, ketanserin, male } \\
\quad \text { vs female }\end{array}$ & 8 & 16 & & Two-way ANOVA & $F_{(1,27)}=3.694$ & 0.0652 & $\begin{array}{l}\text { Main effect } \\
\text { (treatment) }\end{array}$ & & & & & \\
\hline $\begin{array}{l}5 D \text {, ketanserin, male } \\
\quad \text { vs female }\end{array}$ & 8 & 16 & & & & & Male vs female $5-\mathrm{HT}$ & Tukey & 0.880 & 5.30 & -14.31 & 24.92 \\
\hline $\begin{array}{l}5 D \text {, ketanserin, male } \\
\quad \text { vs female }\end{array}$ & 8 & 16 & & & & & $\begin{array}{l}\text { Male 5-HT vs } \\
\quad+\text { ketanserin }\end{array}$ & Tukey & $>0.999$ & 0.48 & -21.17 & 22.13 \\
\hline $\begin{array}{l}5 D \text {, ketanserin, male } \\
\quad \text { vs female }\end{array}$ & 8 & 16 & & & & & $\begin{array}{c}\text { Female 5-HT vs } \\
\text { + ketanserin }\end{array}$ & Tukey & 0.0007 & -30.06 & -48.41 & -11.71 \\
\hline $\begin{array}{l}5 D \text {, ketanserin, male } \\
\quad \text { vs female }\end{array}$ & 8 & 16 & & & & & $\begin{array}{c}\text { Female ketanserin vs } \\
\text { Male ketanserin }\end{array}$ & Tukey & 0.0116 & -25.24 & -45.75 & -4.72 \\
\hline $\begin{array}{l}\text { 6Bz, sEPSC intere- } \\
\text { vent male vs } \\
\text { female }\end{array}$ & 8 & 17 & Yes & Kolmogorov-Smirnov & 0.6455 & $<0.0001$ & Difference & & & 177.7 & 168.00 & 187.30 \\
\hline $\begin{array}{l}6 D, \text { sEPSC fre- } \\
\text { quency male vs } \\
\text { female and } 5-\mathrm{HT}\end{array}$ & 8 & 17 & Yes & Two-way ANOVA & $F_{(1,30)}=0.0402$ & 0.842 & Interaction & & & & & \\
\hline $\begin{array}{l}6 D \text {, sEPSC fre- } \\
\text { quency male vs } \\
\text { female }\end{array}$ & 8 & 17 & Yes & Two-way ANOVA & $F_{(1,30)}=20.52$ & $<0.0001$ & Main effect (sex) & & & & & \\
\hline $\begin{array}{l}6 D, \text { sEPSC fre- } \\
\text { quency } 5-\mathrm{HT}\end{array}$ & 8 & 17 & Yes & Two-way ANOVA & $F_{(1,30)}=0.1990$ & 0.6590 & Main effect $(5-\mathrm{HT})$ & & & & & \\
\hline $\begin{array}{l}6 D \text {, sEPSC fre- } \\
\text { quency male vs } \\
\text { female }\end{array}$ & 8 & 17 & & & & & $\begin{array}{l}\text { Male vs Female } \\
\text { baseline sEPSC }\end{array}$ & Tukey & 0.011 & 12.31 & 2.30 & 22.32 \\
\hline $\begin{array}{l}\text { 6D, sEPSC fre- } \\
\text { quency male vs } \\
\text { female and } 5-\mathrm{HT}\end{array}$ & 8 & 17 & & & & & $\begin{array}{c}\text { Male baseline vs } \\
\text { male 5-HT }\end{array}$ & Tukey & 0.970 & 1.68 & -8.62 & 11.98 \\
\hline $\begin{array}{l}\text { 6D, sEPSC fre- } \\
\text { quency male vs } \\
\text { female and } 5-\mathrm{HT}\end{array}$ & 8 & 17 & & & & & $\begin{array}{c}\text { Female baseline vs } \\
\text { female } 5-\mathrm{HT}\end{array}$ & Tukey & 0.998 & 0.64 & -9.07 & 10.35 \\
\hline $\begin{array}{c}6 E, \text { sEPSC ampli- } \\
\text { tude } 5-\mathrm{HT}\end{array}$ & 8 & 17 & Yes & Two-way ANOVA & $F_{(1,30)}=0.0016$ & 0.9680 & Interaction & & & & & \\
\hline $\begin{array}{c}6 E, \text { sEPSC ampli- } \\
\text { tude } 5-\mathrm{HT}\end{array}$ & 8 & 17 & Yes & Two-way ANOVA & $F_{(1,30)}=0.0085$ & 0.9270 & Main effect (sex) & & & & & \\
\hline $\begin{array}{l}\text { 6ED, sEPSC ampli- } \\
\text { tude } 5-\mathrm{HT}\end{array}$ & 8 & 17 & Yes & Two-way ANOVA & $F_{(1,30)}=0.0054$ & 0.9418 & Main effect (5-HT) & & & & & \\
\hline $7 B, 10-\mathrm{Hz}$ train & 8 & 21 & $\mathrm{~N} / \mathrm{A}$ & Two-way ANOVA & $F_{(1,20)}=6.100$ & 0.0226 & Treatment & & & 8.86 & -26.95 & 44.67 \\
\hline $7 B, 20-\mathrm{Hz}$ train & 8 & 19 & N/A & Two-way ANOVA & $F_{(1,18)}=4.618$ & 0.0455 & Treatment & & & 3.97 & -36.12 & 44.06 \\
\hline
\end{tabular}


Table 2: Continued

\begin{tabular}{|c|c|c|c|c|c|c|c|c|c|c|c|c|}
\hline Figure reported & $\begin{array}{l}N, \\
\# \text { rats }\end{array}$ & $\begin{array}{l}n, \\
\# \text { cells }\end{array}$ & $\begin{array}{l}\text { Norm. } \\
\text { dist?* }\end{array}$ & Statistic & $\begin{array}{l}\text { Statistic } \\
\text { value } \\
\text { (df) }\end{array}$ & $p$ value & $\begin{array}{l}\text { Variance } \\
\text { source }\end{array}$ & $\begin{array}{l}\text { Post hoc } \\
\text { test }\end{array}$ & Post hoc $p$ & $\begin{array}{l}\text { Mean } \\
\text { difference }\end{array}$ & $\begin{array}{l}\text { Lower } \\
95 \% \mathrm{Cl}\end{array}$ & $\begin{array}{l}\text { Upper } \\
95 \% \mathrm{Cl}\end{array}$ \\
\hline $\begin{array}{l}8 B \text {, total cocaine in- } \\
\text { take male-female }\end{array}$ & 17 & N/A & & Unpaired $t$ test & $t_{(22)}=1.463$ & 0.1577 & Difference & & & 4.89 & -2.04 & 11.82 \\
\hline $8 C, C S A, R M P$ & 19 & 45 & Yes & Two-way ANOVA & $F_{(1,35)}=13.26$ & 0.0009 & Interaction & & & & & \\
\hline $8 C, \mathrm{CSA}, \mathrm{RMP}$ & 19 & 45 & & & $F_{(1,35)}=2.279$ & 0.1401 & Main effect (sex) & & & & & \\
\hline $8 C, \mathrm{CSA}, \mathrm{RMP}$ & 19 & 45 & & & $F_{(1,35)}=4.459$ & 0.0419 & $\begin{array}{l}\text { Main effect (treat- } \\
\text { ment-CSA) }\end{array}$ & & & & & \\
\hline $8 C, \mathrm{CSA}, \mathrm{RMP}$ & 19 & 45 & Yes & & & & $\begin{array}{l}\text { Naive male vs naive } \\
\text { female }\end{array}$ & Tukey & 0.520 & -4.50 & -13.30 & 4.30 \\
\hline $8 C, \mathrm{CSA}, \mathrm{RMP}$ & 19 & 45 & Yes & & & & $\begin{array}{l}\text { Naive male vs CSA } \\
\text { male }\end{array}$ & Tukey & 0.0015 & -12.15 & -20.26 & -4.03 \\
\hline $8 C, \mathrm{CSA}, \mathrm{RMP}$ & 19 & 45 & & & & & $\begin{array}{l}\text { CSA male vs CSA } \\
\text { female }\end{array}$ & Tukey & 0.0014 & 10.88 & 3.646 & 18.10 \\
\hline $8 C, \mathrm{CSA}, \mathrm{RMP}$ & 19 & 45 & & & & & $\begin{array}{l}\text { Naive female vs CSA } \\
\text { female }\end{array}$ & Tukey & 0.698 & 3.23 & -4.763 & 11.22 \\
\hline $8 D$, CSA, I-Hold & 30 & 72 & Yes & Two-way ANOVA & $F_{(1,68)}=9.115$ & 0.0036 & Interaction & & & & & \\
\hline $8 D$, CSA, I-Hold & 30 & 72 & & & $F_{(1,68)}=0.0036$ & 0.9521 & Main effect (sex) & & & & & \\
\hline $8 D$, CSA, I-Hold & 30 & 72 & & & $F_{(1,68)}=7.145$ & 0.0094 & $\begin{array}{l}\text { Main effect (treat- } \\
\text { ment-CSA) }\end{array}$ & & & & & \\
\hline $8 D$, CSA, I-Hold & 30 & 72 & & & & & $\begin{array}{l}\text { naive male vs naive } \\
\text { female }\end{array}$ & Tukey & 0.261 & 35.51 & -15.164 & 86.19 \\
\hline $8 D$, CSA, I-Hold & 30 & 72 & & & & & $\begin{array}{l}\text { Naive male vs CSA } \\
\text { male }\end{array}$ & Tukey & $<0.0001$ & 68.32 & 29.495 & 107.15 \\
\hline $8 D$, CSA, I-Hold & 30 & 72 & & & & & $\begin{array}{l}\text { Naive female vs CSA } \\
\text { female }\end{array}$ & Tukey & 0.996 & -4.15 & -54.050 & 45.74 \\
\hline $8 D$, CSA, I-Hold & 30 & 72 & & & & & $\begin{array}{l}\text { CSA male vs CSA } \\
\text { female }\end{array}$ & Tukey & 0.057 & -36.96 & -74.761 & 0.84 \\
\hline $8 E$, firing, male CSA & 8 & 17 & Yes & One-way RM-ANOVA & $F_{(7,21)}=1.288$ & 0.3047 & Treatment & & & -2.421 & -23.500 & 18.70 \\
\hline $\begin{array}{l}8 F \text {, firing, female } \\
\quad \text { CSA }\end{array}$ & 11 & 24 & Yes & One-way RM-ANOVA & $F_{(7,21)}=1.288$ & 0.3047 & Treatment & & & 6.67 & -9.047 & 22.36 \\
\hline $\begin{array}{l}8 G, \text { lhold } 5-\mathrm{HT}, \mathrm{CSA}, \\
\text { male }\end{array}$ & 16 & 39 & $\mathrm{~N} / \mathrm{A}$ & Unpaired $t$ test & $t_{(38)}=0.6226$ & 0.5373 & Treatment & & & -1.625 & -6.909 & 3.66 \\
\hline $\begin{array}{l}8 \mathrm{H} \text {, lhold } 5-\mathrm{HT}, \mathrm{CSA}, \\
\quad \text { female }\end{array}$ & 14 & 30 & $\mathrm{~N} / \mathrm{A}$ & Unpaired $t$ test & $t_{(38)}=0.0742$ & 0.9412 & Treatment & & & -0.290 & -8.154 & 7.58 \\
\hline $\begin{array}{l}\text { 8, data (male female } \\
\text { proportions) }\end{array}$ & 30 & 66 & N/A & Fisher's & N/A & 0.7021 & Treatment & & & $\mathrm{N} / \mathrm{A}$ & N/A & $N / A$ \\
\hline $\begin{array}{l}8 \text { data (male female } \\
\text { days CSA } \\
\text { withdrawal) }\end{array}$ & 30 & 66 & Yes & Unpaired $t$ test & $t_{(17)}=1.733$ & 0.1013 & Sex & & & 18.82 & -4.098 & 41.74 \\
\hline $\begin{array}{l}\text { 9B, sEPSC fre- } \\
\text { quency male vs } \\
\text { female CSA }\end{array}$ & 19 & 43 & Yes & Two-way ANOVA & $F_{(1,39)}=12.05$ & 0.0013 & Interaction & & & & & \\
\hline $\begin{array}{l}\text { 9B, sEPSC fre- } \\
\text { quency male vs } \\
\text { female CSA }\end{array}$ & 19 & 43 & & & $F_{(1,39)}=4.434$ & 0.0417 & Main effect (sex) & & & & & \\
\hline $\begin{array}{l}\text { 9B, sEPSC fre- } \\
\text { quency male vs } \\
\text { female CSA }\end{array}$ & 19 & 43 & & & $F_{(1,39)}=2.057$ & 0.1595 & $\begin{array}{c}\text { Main effect (treat- } \\
\text { ment-CSA) }\end{array}$ & & & & & \\
\hline $\begin{array}{l}\text { 9B, sEPSC fre- } \\
\text { quency male vs } \\
\text { female CSA }\end{array}$ & 19 & 43 & & & & & $\begin{array}{l}\text { Naive male vs naive } \\
\text { female }\end{array}$ & Tukey & 0.0047 & 12.31 & 3.137 & 21.49 \\
\hline $\begin{array}{l}\text { 9B, sEPSC fre- } \\
\text { quency male vs } \\
\text { female CSA }\end{array}$ & 19 & 43 & & & & & $\begin{array}{l}\text { Naive male vs CSA } \\
\text { male }\end{array}$ & Tukey & 0.006 & 10.83 & 2.563 & 19.10 \\
\hline $\begin{array}{l}\text { 9B, sEPSC fre- } \\
\text { quency male vs } \\
\text { female CSA }\end{array}$ & 19 & 43 & & & & & $\begin{array}{l}\text { Naive female vs CSA } \\
\text { female }\end{array}$ & Tukey & 0.494 & -4.50 & -12.984 & 3.99 \\
\hline $\begin{array}{l}\text { 9B, sEPSC fre- } \\
\text { quency male vs } \\
\text { female CSA }\end{array}$ & 19 & 43 & & & (Co & tinued) & $\begin{array}{l}\text { CSA male vs CSA } \\
\text { female }\end{array}$ & Tukey & 0.704 & -3.02 & -10.510 & 4.48 \\
\hline
\end{tabular}


Table 2: Continued

\begin{tabular}{|c|c|c|c|c|c|c|c|c|c|c|c|c|}
\hline Figure reported & $\begin{array}{l}N \\
\# \text { rats }\end{array}$ & $\begin{array}{l}n, \\
\# \text { cells }\end{array}$ & $\begin{array}{l}\text { Norm. } \\
\text { dist? }^{\star}\end{array}$ & Statistic & $\begin{array}{l}\text { Statistic } \\
\text { value } \\
\text { (df) }\end{array}$ & $p$ value & $\begin{array}{l}\text { Variance } \\
\text { source }\end{array}$ & $\begin{array}{l}\text { Post hoc } \\
\text { test }\end{array}$ & Post hoc $p$ & $\begin{array}{l}\text { Mean } \\
\text { difference }\end{array}$ & $\begin{array}{l}\text { Lower } \\
95 \% \mathrm{Cl}\end{array}$ & $\begin{array}{l}\text { Upper } \\
95 \% \mathrm{Cl}\end{array}$ \\
\hline $\begin{array}{l}9 C, \text { sEPSC ampli- } \\
\text { tude male vs fe- } \\
\text { male CSA }\end{array}$ & 19 & 42 & Yes & Two-way ANOVA & $F_{(1,38)}=0.0691$ & 0.8018 & Interaction & & & & & \\
\hline $\begin{array}{l}\text { 9C, sEPSC ampli- } \\
\text { tude male vs fe- } \\
\text { male CSA }\end{array}$ & 19 & 42 & & & $F_{(1,38)}=0.1930$ & 0.6629 & Main effect (sex) & & & & & \\
\hline $\begin{array}{l}9 \mathrm{C}, \mathrm{sEPSC} \text { ampli- } \\
\text { tude male vs fe- } \\
\text { male CSA }\end{array}$ & 19 & 42 & & & $F_{(1,38)}=1.998$ & 0.1657 & $\begin{array}{l}\text { Main effect (treat- } \\
\text { ment-CSA) }\end{array}$ & & & & & \\
\hline $\begin{array}{l}\text { 9D, sEPSC fre- } \\
\text { quency male vs } \\
\text { female CSA, 5-HT }\end{array}$ & 19 & 42 & Yes & Two-way ANOVA & $F_{(1,38)}=0.5817$ & 0.4503 & Interaction & & & & & \\
\hline $\begin{array}{l}\text { 9D, sEPSC fre- } \\
\text { quency male vs } \\
\text { female CSA, } 5-\mathrm{HT}\end{array}$ & 19 & 42 & & & $F_{(1,38)}=0.3550$ & 0.5548 & Main effect (sex) & & & & & \\
\hline $\begin{array}{l}\text { 9D, sEPSC fre- } \\
\text { quency male vs } \\
\text { female CSA, } 5-\mathrm{HT}\end{array}$ & 19 & 42 & & & $F_{(1,38)}=0.095$ & 0.7600 & $\begin{array}{l}\text { Main effect (treat- } \\
\text { ment-CSA) }\end{array}$ & & & & & \\
\hline
\end{tabular}

* D'Agostino-Pearson test of normality.

paradigm. Based on our phenotypic data and finding that only a single copy of the Cre transgene was present in line 2, we designated the line as LE-Tg(PvalbiCre)2Ottc [rat genome database (RGD) ID \#10412329, RRRC line \#773] and refer to this line as Pvalb-iCre for the remainder of the article.

\section{Properties of transfected OFC ${ }^{P V}$ neurons}

Following delivery of $\mathrm{AAV}$ expressing Cre-dependent ChR2-eYFP, we confirmed eYFP fluorescence in OFC and used DIC microscopy to locate cells in spatial register with the fluorescent signal (Fig. 2). Patch clamp recordings in eYFP-positive neurons revealed a significantly
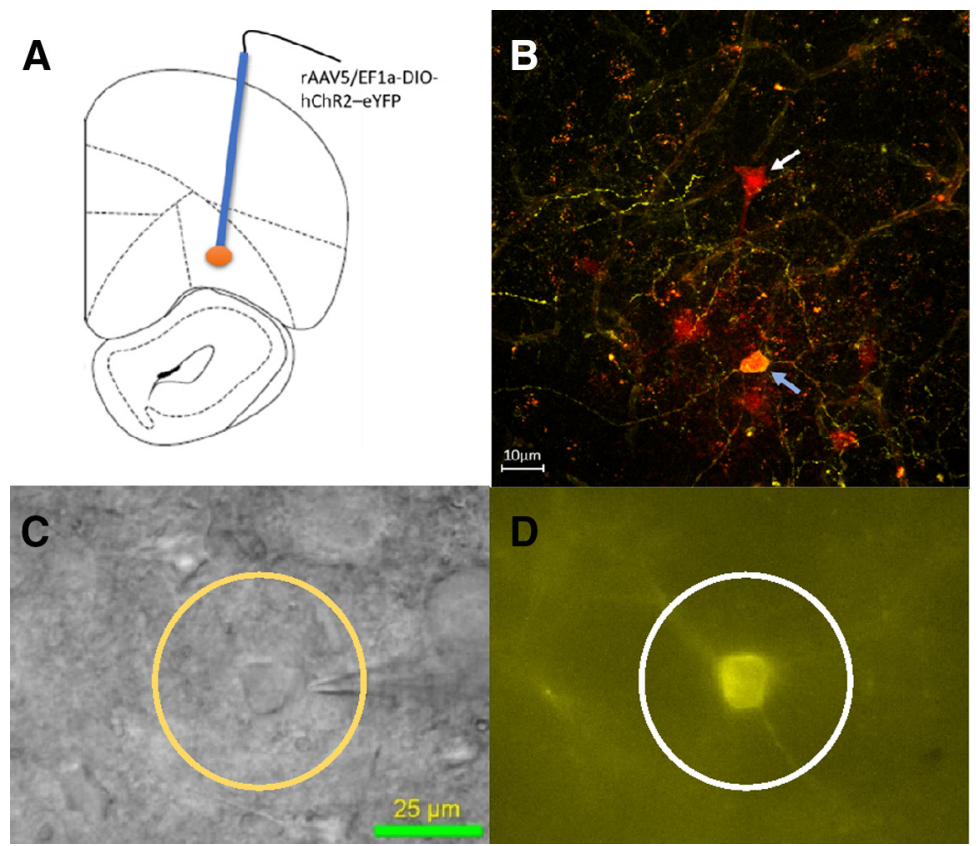

Figure 2. $\boldsymbol{A}$, Schematic illustration of virus injection site in the lateral OFC $(+4.0 \mathrm{~mm}$ anterior of Bregma; $-2.0 \mathrm{~mm}$ from midline, $-4.3 \mathrm{~mm}$ ventral to skull surface; adapted from Paxinos and Watson, 1998). B, OFC PyN filled with biocytin bound to an Alexa Fluor 594 conjugate (white arrow). Also shown is a biocytin-filled cell that also expresses eYFP (blue arrow) in a Pvalb-iCre rat, three weeks after receiving an OFC injection with the ChR2-eYFP viral construct. $\boldsymbol{C}$, DIC video microscopic image showing an OFC neuron (yellow circle) in a living rat brain slice from a Pvalb-iCre rat. A patch electrode is shown to the right ( $v$-shaped structure). $\boldsymbol{D}$, The same neuron (white circle) as in $\boldsymbol{C}$, under fluorescence illumination, and through the same objective in a Pvalb-iCre rat, three weeks after injection with the ChR2-eYFP virus (scale bar for $\boldsymbol{C}, \boldsymbol{D}$ ). 
A

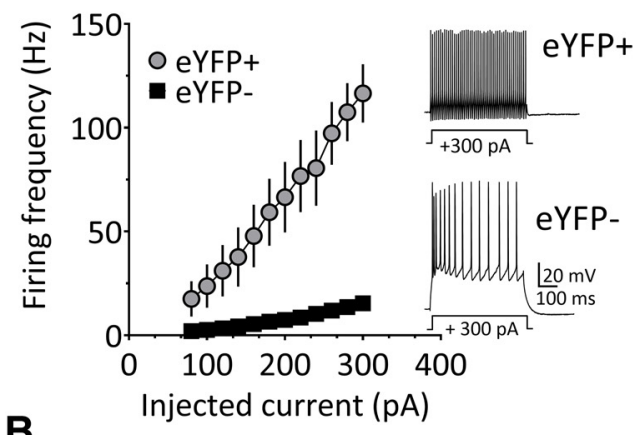

B

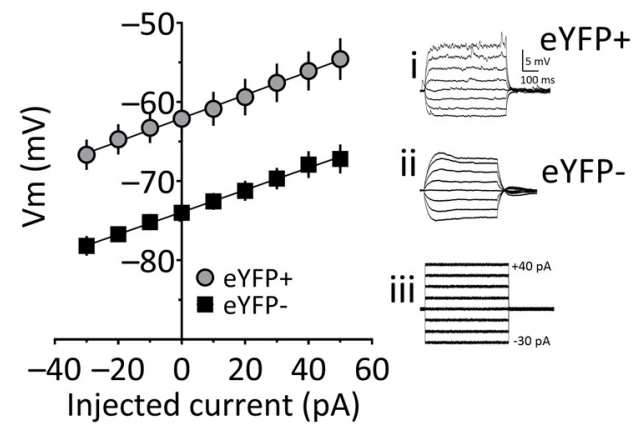

C
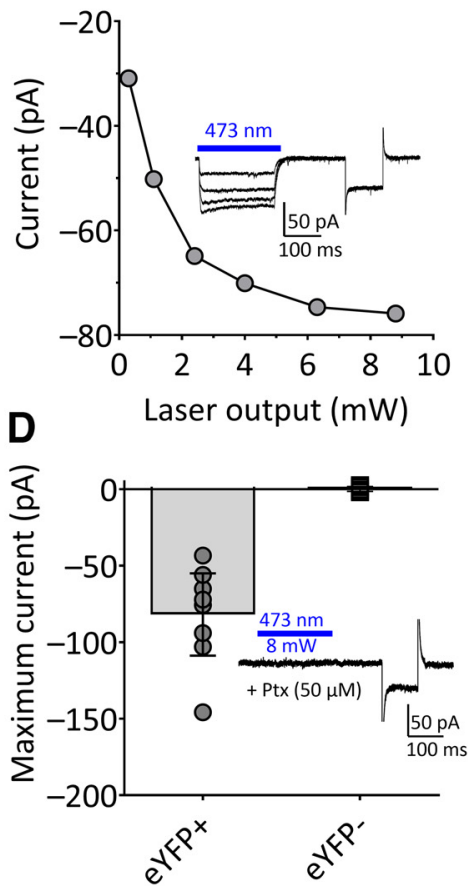

Figure 3. Properties of eYFP-positive (eYFP+) and eYFP-negative (eYFP-) neurons in the OFC of Pvalb-iCre rats, three weeks after injection of viral construct expressing eYFP and ChR2. A, left, Mean effect of depolarizing currents (80-300 pA, 500 ms), passed through whole-cell recording electrodes, on action potential firing frequency in eYFP + and eYFP- cells. eYFP + cells showed a significantly higher frequency of action potential discharge, compared with eYFP- cells (significant interaction between eYFP and current injection; $F_{(11,231)}=30.23$, two-way RM ANOVA). Inset, Representative examples from single cells responding to +300 -pA current injection. $\boldsymbol{B}$, Mean I-V relationships in response to subthreshold current injections $(-30$ to $+50 \mathrm{pA}, 500 \mathrm{~ms})$ in eYFP + and eYFP- cells. Membrane potential measurements were made during the final $20 \mathrm{~ms}$ of the current step. i-iii show membrane voltage responses to current injection in representative eYFP + and eYFP- neurons, as well as the current steps to evoke these responses (iii). $\boldsymbol{C}$, Peak inward currents elicited by ChR2 activation with 473-nm laser light pulses of varying power in a single eYFP + OFC neuron. The inset shows membrane currents in response to different intensities of 473-nm light (blue bar). The later current response is used to measure $R_{\mathrm{in}}$. The cell was voltage clamped at $-65 \mathrm{mV}$. $\boldsymbol{D}$, Mean $\pm 95 \% \mathrm{Cl}$ maximum inward currents indicating that lightevoked responses were observed in eYFP+ cells, and not in eYFP- cells $\left(N, n=4,15\right.$; unpaired $t$ test, $\left.t_{(22)}=5.804, p<0.0001\right)$. In these experiments, GABAergic currents were blocked by picrotoxin (Ptx; $50 \mu \mathrm{m}$ ) to eliminate IPSCs arising from activation of nearby eYFP+ cells.

higher firing frequency in response to square-wave current injection, compared with eYFP-negative cells (significant interaction between eYFP expression and current injection, two-way RM-ANOVA; $F_{(11,231)}=30.23, p<$ 0.0001 ; and significant main effects of firing frequency vs injected current $\left(F_{(11,231)}=51.63, p<0.0001\right)$ and firing rate as a function of YFP expression $\left(F_{(1,21)}=17.61\right.$, $p=0.0004$; Fig. $3 A$ ). The eYFP-positive neurons also exhibited more depolarized resting membrane potentials (RMPs) than eYFP-negative neurons (Fig. 3B), and injection of subthreshold depolarizing current revealed current oscillations in eYFP-positive cells (Fig. 3Ci), that were not seen in eYFP-negative cells (Fig. 3Cii). In addition, the current-voltage $(I-V)$ relationships in eYFP-positive cells were linear (Fig. $3 B$, deviation from linearity, $p=0.26$ ), unlike the profile seen in other interneuron subtypes. As the electrophysiological characteristics observed in eYFPpositive cells matched that of fast-spiking parvalbumin interneurons (Koós and Tepper, 1999; Weber and Andrade, 2010), we refer to these eYFP-positive cells in our PvalbiCre rats as OFC ${ }^{P V}$ neurons.

\section{ChR2-induced activity in OFC ${ }^{P V}$ cells}

Recorded OFC ${ }^{P V}$ cells were stimulated using blue $(473 \mathrm{~nm})$ laser light across a range of power settings (200 ms in duration). Laser stimulation generated stable inward currents without decrement throughout the light pulse, at all power settings (Fig. 3C). In contrast, currents were not observed in eYFP-negative cells in response to laser stimulation (Fig. $3 D, t_{(13)}=6.71, p<0.0001$ ). In a group of recordings from PyNs (eYFP-negative cells), we found that single $5 \mathrm{~ms}$ laser pulses reliably elicited IPSCs (olPSCs; Fig. 4A). These olPSCs had a short $(2.78 \pm$ $1.05 \mathrm{~ms})$ latency to $50 \%$ peak with a small SD $(0.20 \pm$ $0.16 \mathrm{~ms}$, mean $\pm \mathrm{SD}$ ) or "jitter"; both of which suggest that these currents were monosynaptic (Fig. 4A). Pairedpulse laser stimulation at a 50-ms interpulse intervals revealed inhibition of the second oIPSC, relative to the first olPSC (Fig. 4A), and these responses were completely blocked by the selective $\mathrm{GABA}_{A}$ receptor antagonist, SR95531 (gabazine, $10 \mu \mathrm{m}$; Fig. 4B, paired-Student's $t$ test, $\left.t_{(13)}=6.49, p<0.0001\right)$. Thus, ChR2 activation of OFC ${ }^{P V}$ 

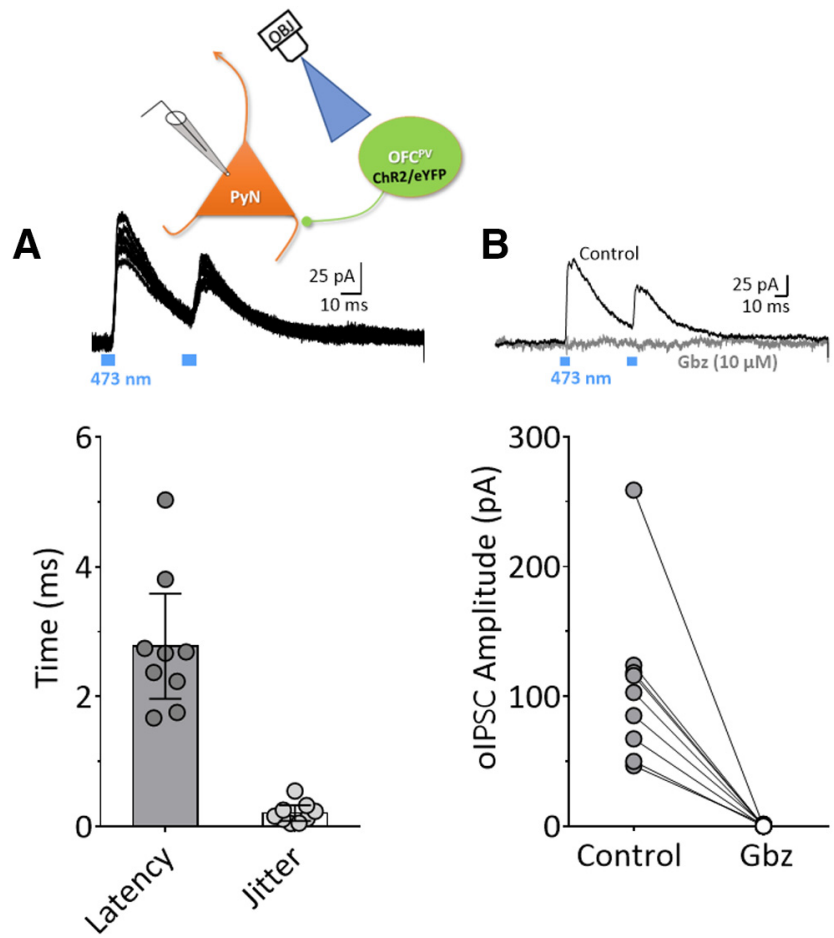

Figure 4. Optogenetic stimulation of $\mathrm{OFC}^{\mathrm{PV}}$ cells evokes monosynaptic IPSCs in OFC PyNs. The diagram indicates the recording and light-stimulation configuration. Recordings were made in OFC PyNs and stimulation of ChR2 expressed in OFC ${ }^{P V}$ neurons with blue light passed through the microscope objective (OBJ). A, top panel, Individual traces of paired (50-ms interval) optical IPSCs (oIPSCs) evoked by stimulation ChR2 with 473-nm light, recorded in an eYFP- cell. Bottom panel, Individual and mean $( \pm 95 \% \mathrm{Cl})$ peak first response to light stimulation showing latency to $50 \%$ peak olPSC $(2.78 \pm 1.05 \mathrm{~ms})$ and jitter $(0.20 \pm$ $0.16 \mathrm{~ms}$ ). $\boldsymbol{B}$, top panel, Representative sample of a paired synaptic response to 473-nm stimulation that is eliminated by the GABA receptor antagonist gabazine (Gbz; $10 \mu \mathrm{M}$, gray trace). Bottom panel, Summary of first olPSC amplitudes recorded from OFC PyNs demonstrating complete elimination of the response by $\mathrm{Gbz}$ $\left(N, n=6,14\right.$, paired $\left.t_{(13)}=6.49, p<0.0001\right)$.

interneurons generates GABAergic inhibition of OFC PyNs in Pvalb-iCre rats.

5-HT Effects in OFC ${ }^{P V}$ cells. Bath application of 5-HT $(20 \mu \mathrm{M})$ elicited inward currents at a holding potential of $65 \mathrm{mV}$ in the majority of OFC ${ }^{\mathrm{PV}}$ cells examined (22 of 28 cells, 11 rats, $78.6 \%$; Fig. $5 A, B$ ), with no change in input resistance $\left(\mathrm{R}_{\text {in }}\right.$; data not shown; one-sample $t_{(21)}=1.25$, $p=0.225$ ). Moreover, the mean largest amplitudes of inward currents in response to $5-\mathrm{HT}$ in $\mathrm{OFC}^{\mathrm{PV}}$ neurons from males and female rats were similar (Fig. $5 A-C$, unpaired $t$ test, $t_{(80)}$ $=0.38, p=0.97)$. A small number of cells $(4 / 28,14.3 \%)$ from only male rats exhibited significant outward currents in response to $20 \mu \mathrm{M}$ 5-HT (Fig. 5C, one-sample $t$ test, $t_{(40)}=$ $7.94, p<0.0001)$, and this was associated with a small decrease in $\mathrm{R}_{\text {in }}$ (data not shown). Given the small proportion of cells showing outward currents, we did not further characterize this response. However, it has previously been shown that similar currents in OFC PyNs in male wild-type rats were mediated by $5 \mathrm{HT}_{1 \mathrm{~A}}$ receptors (Wright et al., 2017).
In OFC ${ }^{P V}$ neurons from female rats, inward currents were blocked by pretreatment of brain slices with ketanserin $(10 \mu \mathrm{M})$, a 5- $\mathrm{HT}_{2 \mathrm{~A} / 2 \mathrm{C}}$ receptor antagonist (Fig. 5B,D), but ketanserin did not change the peak effect of 5-HT in $\mathrm{OFC}^{\mathrm{PV}}$ neurons from male rats (Fig. $5 A, D$, two-way ANOVA sex $\times$ treatment interaction, $F_{(1,27)}=8.67, p=$ 0.0066 , main effect of sex, $F_{(1,27)}=8.14, p=0.0082$, main effect of treatment, $\left.F_{(1,27)}=3.70, p=0.0652\right)$. Moreover, although post hoc analysis (Tukey) indicated no difference between males and females with regard to the basal effect of 5-HT on inward currents in OFC ${ }^{P V}$ neurons $(p=0.881)$, there was a significant effect of ketanserin in females $(p=0.0007)$, but not in males $(p>0.999)$.

\section{5-HT does not alter glutamatergic transmission onto OFC ${ }^{P V}$ cells}

In addition to its postsynaptic effects, 5-HT increases glutamatergic transmission onto OFC PyNs, likely via depolarization of these cells and release of glutamate from PyN to PyN collateral synapses. We therefore examined properties of glutamate synaptic transmission onto $\mathrm{OFC}^{\mathrm{PV}}$ cells, and whether this was modulated by $5-\mathrm{HT}$, by recording SEPSCs in these neurons. An interaction between sex and treatment (5-HT effect) on SEPSC frequency was not significant using a two-way ANOVA $\left(F_{(1,30)}=0.040\right.$, $p=0.842$; Fig. $6 A-D)$, nor was there a significant main effect of treatment with 5-HT on sEPSC frequency $\left(F_{(1,30)}=0.200\right.$, $p=0.658$ ). However, there was a significant main effect of sex on the frequency of sEPSCs $\left(F_{(1,30)}=20.52, p<0.0001\right)$. Post hoc analysis revealed that the frequency of sEPSCs were significantly higher in OFC ${ }^{P V}$ cells from males in the baseline condition ( $p=0.0113$, Tukey's post hoc test) and that $5-\mathrm{HT}$ had no effect of $s E P S C$ frequency in these cells from males or females ( $p=0.970, p=0.997$, respectively). In contrast to this baseline difference in SEPSC frequency between males and females, mean sEPSC amplitudes were not significantly different (Fig. 6E), nor did 5-HT alter this measure (Fig. 6E, two-way ANOVA, $F_{(1,30)}=0.00164$, $p=0.97$ ). Thus, basal synaptic glutamate input is stronger in male rat OFC ${ }^{P V}$ neurons, and this is not altered by $5-\mathrm{HT}$ in males or females.

\section{5-HT increases GABAergic transmission onto OFC PYRs}

As shown above, 5-HT evoked inward depolarizing currents in the majority of GABAergic OFC ${ }^{\mathrm{PV}}$ neurons, and these cells are synaptically connected to OFC PyNs (Figs. $4,5)$. Therefore, we hypothesized that $5-\mathrm{HT}$ would increase ChR2-evoked GABAergic olPSCs recorded in OFC PyNs. Since parvalbumin interneurons can sustain high rates of firing, we activated OFC ${ }^{P V}$ cells with 473-nm light stimulus trains (10 pulses at 10 or $20 \mathrm{~Hz}$; laser power set to evoke olPSCs at $75 \%$ of maximum) to activate olPSCs in PyNs. 5-HT $(20 \mu \mathrm{M})$ significantly increased the amplitude of oIPSCs between $\sim 5 \%$ and $16 \%$ for the 10 $\mathrm{Hz}$ trains and $5 \%$ and $17 \%$ for the $20-\mathrm{Hz}$ trains (Fig. $7 A, B$, RM two-way ANOVA; $10-\mathrm{Hz}$ train $=F_{(1,20)}=6.1, p=0.023$; $20-\mathrm{Hz}$ train $\left.=F_{(1,18)}=4.618, p=0.045\right)$. Roughly half $(N=8$ rats, 11 of 21 cells, $52.4 \%$ ) of the cells demonstrated an increase in olPSCs in response to 5-HT, while a few (four of 21 cells, $19.0 \%)$ showed a decrease. The remaining cells (6 of $21,28.6 \%$ ) showed no change on $5-\mathrm{HT}$ 

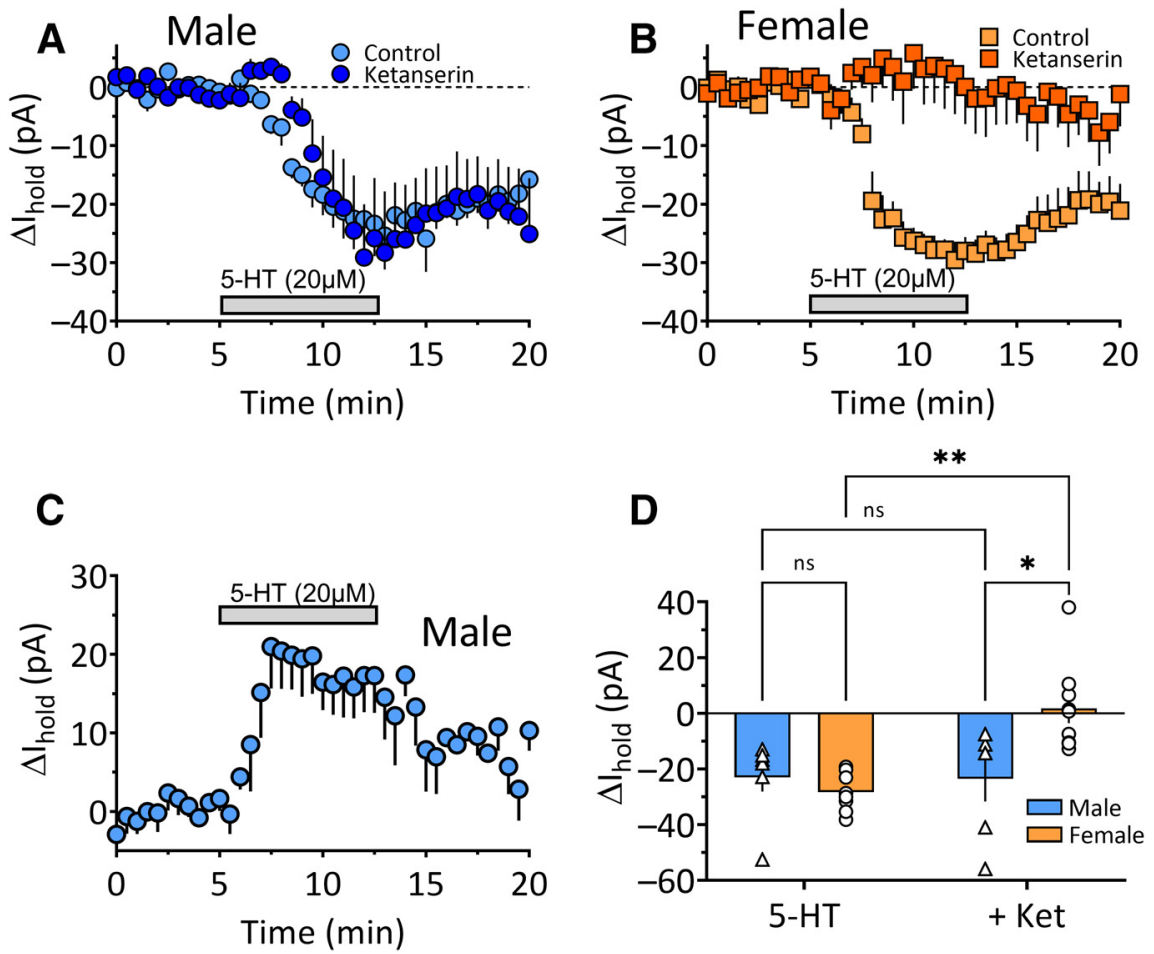

Figure 5. Effects of 5- $\mathrm{HT}$ and the $5-\mathrm{HT}_{2 \mathrm{~A} / 2 \mathrm{C}}$ antagonist ketanserin (Ket; $10 \mu \mathrm{M}$ ) on $\mathrm{OFC}^{\mathrm{PV}}$ cell $\mathrm{I}_{\text {holds }}$ in cocaine-naive rats. $\boldsymbol{A}$, Time course of mean $( \pm$ SEM) inward currents caused by bath application of $5-\mathrm{HT}(20 \mu \mathrm{M}$, horizontal gray bar) alone, or during treatment with ketanserin in male Pvalb-iCre rats $(N, n=7,13)$. Inward currents with $5-\mathrm{HT}$ alone were observed in the majority of OFC ${ }^{P V}$ neurons in males and females (22/28 cells, 11 rats, $78.6 \%)$. B. Time course of mean ( \pm SEM) inward currents caused by bath application of 5-HT alone, or during application of ketanserin in female Pvalb-iCre rats $(N, n=4,11)$. C, Mean ( \pm SEM) outward 5 -HT-induced currents were observed in a minority of male OFC ${ }^{\mathrm{PV}}$ cells $(4 / 28$ cells, $14.3 \%)$. $\boldsymbol{D}$, Mean maximal effects of $5-\mathrm{HT}$ alone, or during application of ketanserin in OFC ${ }^{P V}$ neurons from male and female Pvalb-iCre rats. The effects of 5-HT under control and ketanserin conditions were obtained by averaging data across the final 3 min of the 5-HT application periods shown in $\boldsymbol{A}, \boldsymbol{B}$. Note that although the magnitudes of the 5-HT-induced inward currents did not differ between male and female OFC ${ }^{\mathrm{PV}}$ neurons in the control condifontstion, they were significantly blocked by ketanserin only in female Pvalb-iCre rats (two-way ANOVA, sex $\times$ treatment interaction $F_{(1,27)}=8.671, p=0.0066$; Tukey's post hoc comparisons, male 5-HT vs ketanserin $p>0.9999$, female 5-HT vs ketanserin, ${ }^{*} p=0.0007$, male vs female ketanserin, $\left.{ }^{*} p=0.0116\right)$. ns, not significant.

application. There were no differences in the magnitude of the 5-HT-induced increase in oIPSC amplitude in $\mathrm{OFC}^{\mathrm{PV}}$ cells between male and female rats (data not shown), nor in the proportion of cells showing the 5-HT increase in oIPSCs. Together, these data suggest that 5-HT increases OFC ${ }^{P V}$ neuron inhibition of OFC PyNs and that this does not differ between male and female rats.

Effects of CSA withdrawal on OFC ${ }^{P V}$ neurons. Although small differences in the rates of lever pressing were noted between male and female Pvalb-iCre rats during earlier sessions of acquisition of CSA, this became similar and stable in both sexes by the end of training (Fig. $8 A$ ). Moreover, there was no difference in the total amount of cocaine intake between male and female rats at the end of this training (Fig. $8 B, t_{(15)}=1.02, p>0.05$, unpaired $t$ test).

OFC $C^{P V}$ neuron membrane properties are altered after withdrawal from CSA

Following $14 \mathrm{~d}$ of CSA training, rats were returned to their home cages for $55.7 \pm 5.7 \mathrm{~d}$ (mean \pm SEM) until electrophysiology experiments were conducted. Male and female rats were withdrawn from CSA for a similar number of days $(45.8 \pm 4.6$ and $64.6 \pm 9.4 \mathrm{~d}$, respectively, $t_{(17)}=1.733, p=0.101$, unpaired $t$ test). RMP, holding current ( $I_{\text {hold }}$; obtained at $-65 \mathrm{mV}$ ) and $\mathrm{R}_{\text {in }}$, were measured in OFC ${ }^{P V}$ cells from naive rats and those withdrawn from CSA. Cells from male, but not female animals, demonstrated significantly less negative (depolarized) RMPs after withdrawal from CSA (Fig. 8C, two-way ANOVA, treatment $\times$ sex interaction, $F_{(1,35)}=13.26, p=0.0009$; treatment main effect $F_{(1,35)}=4.459, p=0.0419$; sex main effect, $F_{(1,35)}=2.279, p=0.1401$ ) post hoc analysis (Tukey's) showed that there was no difference in OFC ${ }^{P V}$ RMPs in between naive females and males $(p=0.520)$, that there was a significant effect of CSA on RMP in only males $(p=0.0015)$ demonstrated by a significant difference between females and males after CSA $(p=0.0014)$. Consistent with the change in OFC ${ }^{P V}$ RMP values from male rats, the amount of current necessary to voltage clamp these cells at $-65 \mathrm{mV}\left(\mathrm{l}_{\mathrm{hold}}\right)$ was larger and more negative in $\mathrm{OFC}^{\mathrm{PV}}$ neurons from male rats after withdrawal from CSA (Fig. 8D, two-way ANOVA, treatment $x$ sex interaction, $F_{(1,68)}=9.115, p=0.0036$; treatment main 
A
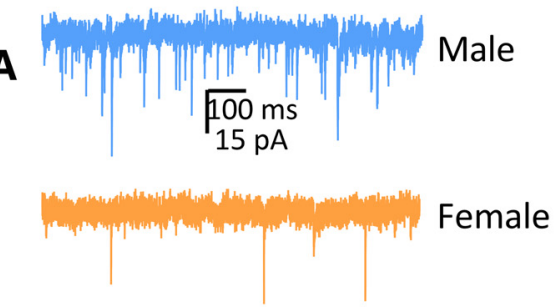

B

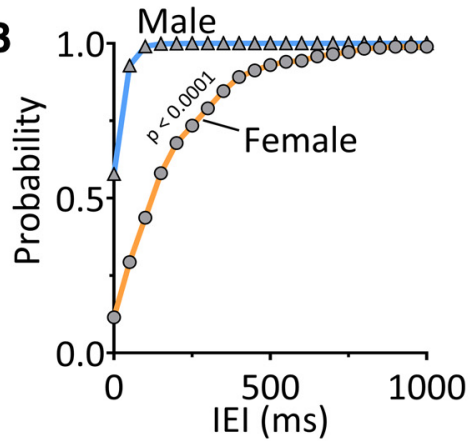

C

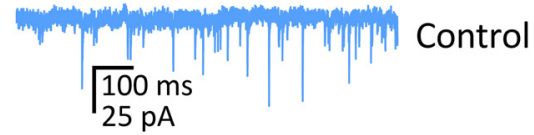
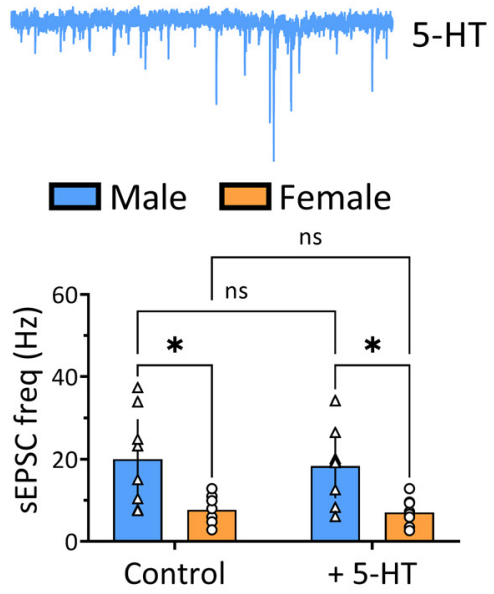

E

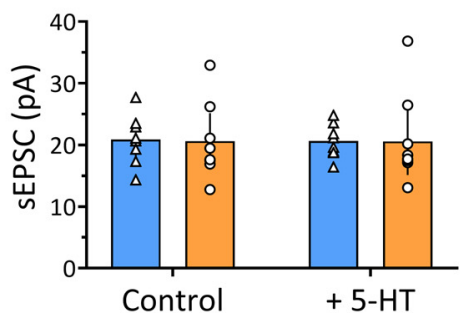

Figure 6. Excitatory transmission onto $\mathrm{OFC}^{\mathrm{PV}}$ cells differs between male and female rats and is insensitive to 5-HT. $\boldsymbol{A}$, Representative traces of SEPSCs from male and female OFC ${ }^{P V}$ cells from Pvalb-iCre rats. $\boldsymbol{B}$, Mean cumulative probability histogram of interevent intervals (IEIs) showing significantly $\left(p<0.0001\right.$, Kolmogorov-Smirnov test) larger intervals between sEPSC in OFC ${ }^{P V}$ cells from naive female rats, compared with males. $\boldsymbol{C}$, Representative sEPSC traces in an OFC ${ }^{P V}$ neuron from a male rat before (control) and during $5-\mathrm{HT}(20 \mu \mathrm{M})$ application. $\boldsymbol{D}$, Mean $( \pm 95 \% \mathrm{Cl})$ sEPSC frequency recorded in OFC ${ }^{\mathrm{PV}}$ neurons in male and female Pvalb-iCre rats. SEPSC frequency was significantly lower in cells from female rats (significant main effect of sex, $F_{(1,30)}=20.52$, $p<0.0001$, two-way ANOVA; $p=0.011$, Tukey's post hoc test), but $5-\mathrm{HT}$ application did not significantly change sEPSC frequency in males or females (main effect of treatment, $F_{(1,30)}=0.199, p=0.66$, two-way ANOVA; $p=0.011, p=0.97$, and $p=0.99$, respectively, Tukey's post hoc test). ${ }^{*} p<0.05$, Tukey's post-hoc test. $\boldsymbol{E}$, Mean $( \pm 95 \% \mathrm{Cl})$ sEPSC amplitudes recorded in OFC ${ }^{\mathrm{PV}}$ neurons in male and female Pvalb-iCre rats during baseline, and 5-HT application periods. The sEPSC amplitudes did not differ between male and female rats, and there were no significant effects of 5 -HT on SEPSC amplitude $\left(F_{(1,30)}=0.00164, p=0.97\right.$, two-way ANOVA). ns, not significant.

effect, $F_{(1,68)}=7.145, p=0.0094$; sex main effect, $F_{(1,68)}=$ $0.0036, p=0.9521)$. Post hoc analysis showed that the effect of CSA on Ihold in males was significant $(p<0.0001)$. In contrast to the effects of CSA on RMP and $I_{\text {hold }}$ in $\mathrm{OFC}^{\mathrm{PV}}$ neurons from male rats, no changes in the relationship between injected current and firing frequency was observed in any of the groups after CSA (Fig. 8E,F, RMANOVA, $\left.F_{(7,21)}=1.288, p=0.304\right)$. These data suggest that whereas $\mathrm{OFC}^{\mathrm{PV}}$ neurons from only male rats are more depolarized following CSA, this has little effect on neuronal output in response to depolarizing current injection.

Effects of 5-HT on OFC ${ }^{P V}$ neurons after withdrawal from CSA. Withdrawal from cocaine did not affect the magnitude of mean change in Inold caused by 5-HT (20 $\mu \mathrm{M}$ ) in $\mathrm{OFC}^{\mathrm{PV}}$ neurons from male or female Pvalb-iCre rats after withdrawal from CSA (Fig. 8G,H, unpaired $t$ test, male $t_{(38)}=0.623, p=0.5373$; female $t_{(38)}=0.0742$, $p=0.941)$. Furthermore, the proportion of cells showing inward currents with 5-HT was not changed after withdrawal from CSA (Fisher's exact test, $p=0.702$ ).

The significantly higher frequency of sEPSCs in naive male rats compared with naive females noted in Figure 6 can also be seen in Figure 9B. After withdrawal from CSA, a significant decrease in SEPSC frequency was observed in OFC ${ }^{P V}$ neurons from male rats, but no changes in sEPSC frequency were seen in cells from female rats (Fig. $9 A, B$, two-way ANOVA, treatment $\times$ sex interaction, $F_{(1,39)}=12.05, p=0.0013$; sex main effect, $F_{(1,39)}=4.43$, $p=0.0417$; treatment main effect, $F_{(1,39)}=2.057, p=0.1595$; Tukey's post hoc test, naive male vs CSA male, $p=0.0060$; naive female vs CSA female, $p=0.9586$ ). Withdrawal from CSA had no effect on sEPSC amplitudes (Fig. 9C, two-way ANOVA, treatment $\times$ sex interaction, $F_{(1,38)}=0.0639$, $p=0.8018$ ). As noted above, 5-HT had no effects on sEPSCs in OFC ${ }^{P V}$ neurons from naive animals (Fig. $6 D, E$ ). Similarly, after withdrawal from CSA, 5-HT failed to alter the amplitudes (means \pm SEM, male CSA control=19.35 \pm 

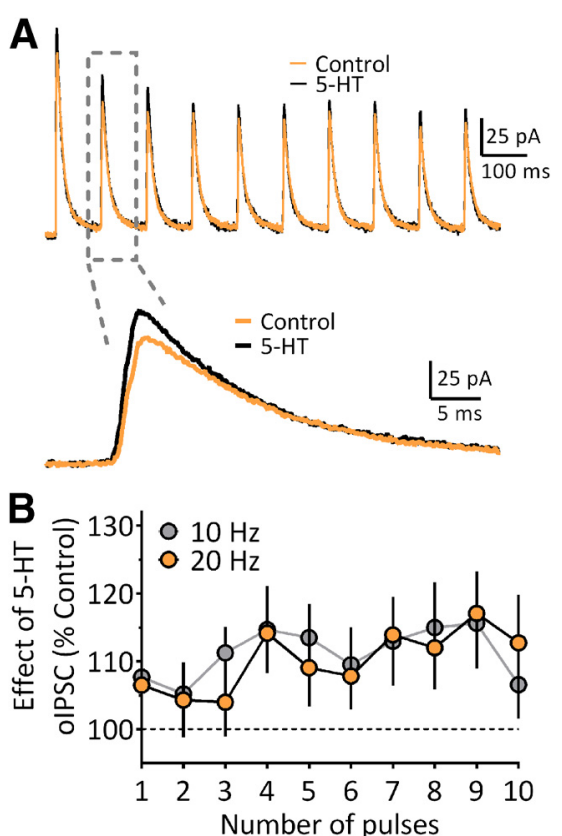

Figure 7. Effects of 5-HT on trains of olPSCs recorded in OFC PyNs following light-activation of OFC ${ }^{P V}$ cells. The recording configuration is the same as described in Figure 4. $\boldsymbol{A}$, Traces of olPSCs obtained from an OFC PyN before (control, orange line) and during 5- $\mathrm{HT}(20 \mu \mathrm{M})$ application (black line). The lower traces are those shown in the gray dashed box, plotted on an expanded timescale. $\boldsymbol{B}$, Mean $( \pm S E M)$ of the effect of $5-\mathrm{HT}$ on trains of olPSCs evoked at $10 \mathrm{~Hz}(n=21$ cells) or $20 \mathrm{~Hz}$ ( $n=19$ cells), expressed as a percentage of control responses recorded before 5-HT-application. The oIPSCs activated at both frequencies were significantly increased by 5-HT (RM two-way ANOVA; $10-\mathrm{Hz}$ train, treatment effect = $F_{(1,20)}=6.1, p=0.023 ; 20-\mathrm{Hz}$ train, treatment effect $=F_{(1,18)}=$ 4.618, $p=0.045)$.

$0.85 \mathrm{pA}, \mathrm{CSA} 5-\mathrm{HT}=18.81 \pm 0.892 \mathrm{pA}$; female CSA control $=$ $18.45 \pm 0.99 \mathrm{pA}$, female CSA $5-\mathrm{HT}=19.27 \pm 0.71 \mathrm{pA}$; data not shown) or frequencies of SEPSCs (Fig. 9D, sex $\times$ treatment interaction, two-way ANOVA $F_{(1,38)}=0.582, p=0.450$, main effect sex $F_{(1,38)}=0.355, p=0.555$, main effect of treatment $\left.F_{(1,38)}=0.095, p=0.760\right)$. Together, these data indicate that withdrawal from CSA is associated with a decrease in glutamatergic transmission onto OFC $\mathrm{PV}^{\mathrm{PV}}$ interneurons in only male rats, and that $5-\mathrm{HT}$ has no effect on glutamate release in these neurons in naive or CSA male or female Pvalb-iCre rats.

\section{Discussion}

A growing body of evidence shows that 5-HT innervation of cortical areas is important for the expression of cognitive flexibility, as defined in tasks requiring a change in behavioral strategy to obtain reward. In marmosets, OFC 5-HT depletion impairs visual discrimination reversal (Clarke et al., 2004), and studies tapping similar cognitive domains in rodents show congruent results (Roberts, 2011; Izquierdo et al., 2012; West et al., 2013). More specifically, rodent studies show that 5HT depletion produces deficits in behavioral tasks that require intact OFC $5-\mathrm{HT}$ function to permit cognitive flexibility (Izquierdo et al., 2012; West et al., 2013; Roberts, 2011). Psychostimulants such as methamphetamine and cocaine also negatively affect OFC-dependent information processing, and in many cases, this is seen several weeks after cessation of drug exposure. Thus, long-lasting learning impairments in contingency reversal (Jentsch et al., 2002; Schoenbaum et al., 2004; Calu et al., 2007), reinforcer devaluation (Schoenbaum and Setlow, 2005), and in Pavlovian overexpectation tasks (Takahashi et al., 2013; Lucantonio et al., 2014) are reported. Moreover, the enduring nature of these deficits after withdrawal from selfadministration of psychostimulants in animal models suggests that they may be involved in the dysregulated behavior that is observed in addiction to these drugs.

Links between cocaine and the 5-HT system have been documented at several levels of analysis. Cocaine is a potent inhibitor of the serotonin transporter (SERT; Torres et al., 2003), where it might act to alter 5-HT receptor function to indirectly alter OFC-dependent behavior. In support of this, the deleterious effects of CSA on OFCdependent reversal learning are reduced in mice lacking the SERT (Nonkes et al., 2013), and some cocaine-induced behavioral changes are absent in mutant mice expressing SERT with reduced affinity for this drug (Simmler et., 2017). Based on these findings, it has been hypothesized that 5-HT signaling is involved in the contribution the OFC to cognitive flexibility, and that psychostimulant exposure may disrupt this 5 -HT function in this capacity (Roberts, 2011; Wright et al., 2017; Hankosky et al., 2018). In this regard, our recent data also show profound changes to 5-HT signaling in OFC PyNs in rats withdrawn from CSA or yoked cocaine administration, and that this 5-HT hypofunction could be observed many weeks after withdrawal from cocaine (Wright et al., 2017). The changes included a decrease in 5-HT-induced inhibition of OFC PyNs via $5-\mathrm{HT}_{1 \mathrm{~A}}$ receptors, and a reduction in the ability of $5-\mathrm{HT}_{2 \mathrm{~A}}$ receptors to increase synaptic glutamate release. Although these data show 5-HT hypofunction in OFC PyNs following cocaine exposure, other potential sites of $5-\mathrm{HT}$ interaction with the local OFC circuitry have not been studied. Thus, $5-\mathrm{HT}_{2}$ receptors are also highly expressed on cortical GABAergic interneurons (Liu et al., 2007), and analogous fast-spiking parvalbumin cells in the medial PFC are depolarized by $5-\mathrm{HT}_{2 \mathrm{~A}}$ receptors (Weber and Andrade, 2010; Athilingam et al., 2017). To determine whether CSA alters 5-HT signaling in OFC ${ }^{P V}$ neurons, we developed a novel Pvalb-iCre transgenic rat line in which Cre recombinase expression is driven by the parvalbumin promoter. Cre-dependent expression of eYFP in the OFC of Pvalb-iCre rats was then used to study 5$\mathrm{HT}$ signaling in OFC ${ }^{\mathrm{PV}}$ cells in both naive rats and in those withdrawn from CSA. Additionally, as clinical studies show clear sex-dependent differences in vulnerability to CUD, with females more vulnerable to all phases of drug use, and similar results observed in animal models of addiction (Carroll and Anker, 2010), we powered our study to distinguishing potential differences between males and female Pvalb-iCre rats with regard to effects of CSA and altered 5-HT signaling. 

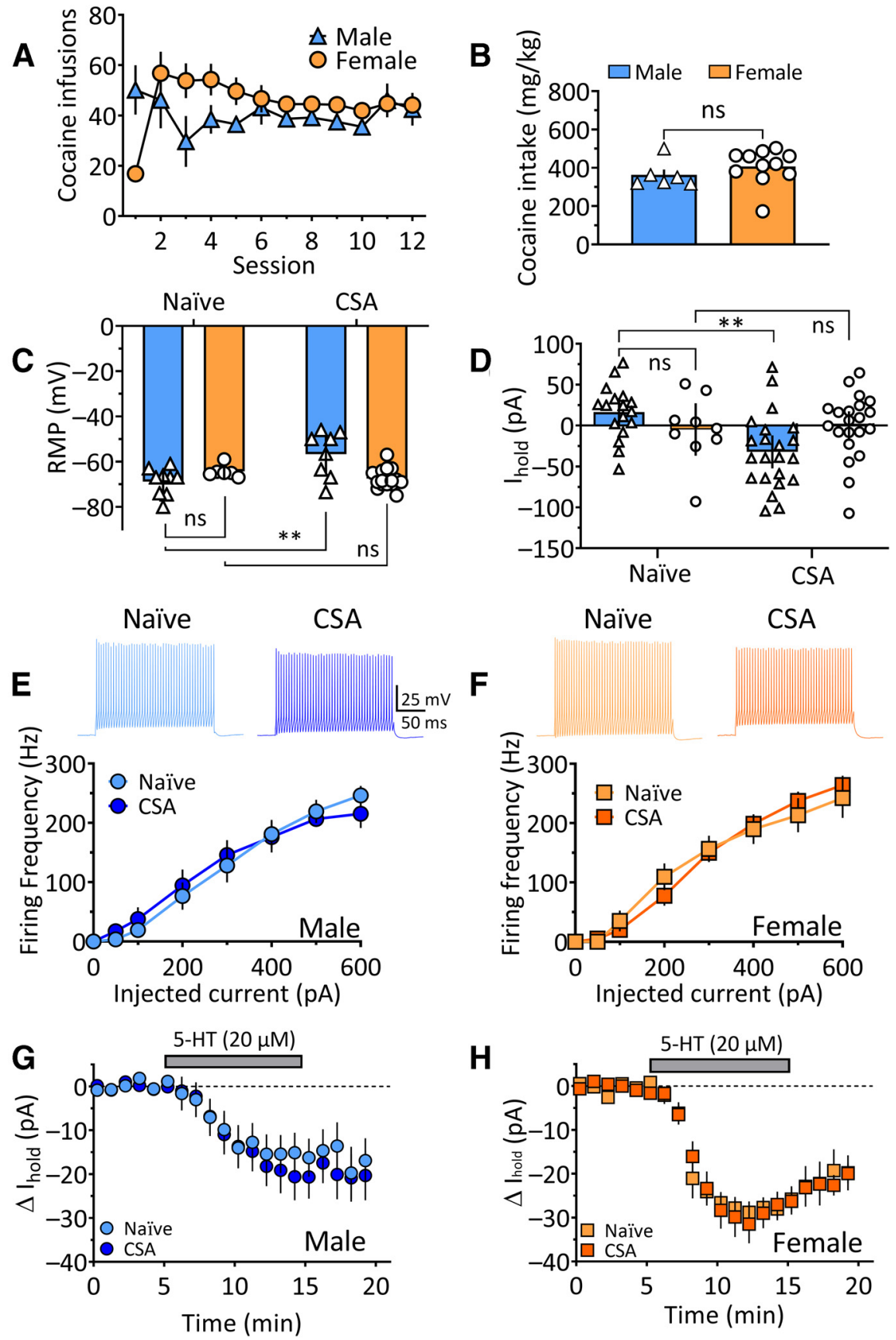

Figure 8. $\mathrm{OFC}^{\mathrm{PV}}$ interneuron membrane properties and sensitivity to 5-HT following CSA in male and female Pvalb-iCre rats. $\boldsymbol{A}$, Mean number of lever presses for cocaine in male and female Pvalb-iCre rats. $\boldsymbol{B}$, Mean cocaine intake for all Pvalb-iCre rats across all self-administration trials. Male and female rats self-administered a similar amount of cocaine (unpaired $t$ test, $t_{(22)}=1.46$, $p=0.158)$. Legend applies to $\boldsymbol{C}, \boldsymbol{D}$. $\boldsymbol{C}$, Mean $( \pm 95 \% \mathrm{Cl}) \mathrm{RMP}$ of OFC ${ }^{\mathrm{PV}}$ neurons from naive male and female rats and those withdrawn from CSA. Cells from male rats were significantly depolarized (less negative RMP) following CSA withdrawal (two-way ANOVA, sex $\times$ treatment interaction, $\left.F_{(1,35)}=13.26, p=0.0009\right)$; male naive versus male CSA (**Tukey's post hoc test, $\left.p=0.0015\right)$, whereas those from females were unchanged (ns, $p=0.70$, Tukey's post hoc test). ${ }^{\star *} p<0.01$, Tukey's post-hoc test. $\boldsymbol{D}$, Mean $( \pm 95 \% \mathrm{Cl}) I_{\text {hold }}$ necessary to voltage clamp OFC ${ }^{P V}$ cells at $-65 \mathrm{mV}$. Consistent with the changes in RMP, cells from male rats required more $I_{\text {hold }}$ after CSA (two-way ANOVA, sex $\times$ treatment interaction, $F_{(1,68)}=9.115, p=0.0036$; male naive vs male CSA, $p$ $<0.0001$, Tukey's post hoc test), and cocaine exposure did not change $I_{\text {hold }}$ in OFC ${ }^{\text {PV }}$ neurons from female rats (female naive vs female CSA, $p=0.9962$, Tukey's post hoc test). ${ }^{* *} p<0.01$, Tukey's post-hoc test. $\boldsymbol{E}, \boldsymbol{F}$, Withdrawal from CSA did not alter the action potential discharge frequency of OFC ${ }^{P V}$ cells caused by depolarizing current injection in either males or females (two-way ANOVA, $\left.F_{(7,21)}=1.288, p=0.3047\right)$. $G, \boldsymbol{H}$, Mean time course of the effects of $5-\mathrm{HT}$ on $\mathrm{I}_{\text {hold }}$ in OFC ${ }^{\mathrm{PV}}$ neurons from male and female naive and CSA rats. No changes in the sensitivity of OFC ${ }^{P V}$ neurons to $5-\mathrm{HT}$ were observed in cells from males (unpaired $t$ test, $t_{(38)}=0.6226$, $p=0.5373)$ or females $\left(t_{(38)}=0.0742, p=0.9412\right)$ following withdrawal from CSA. ns, not significant. 


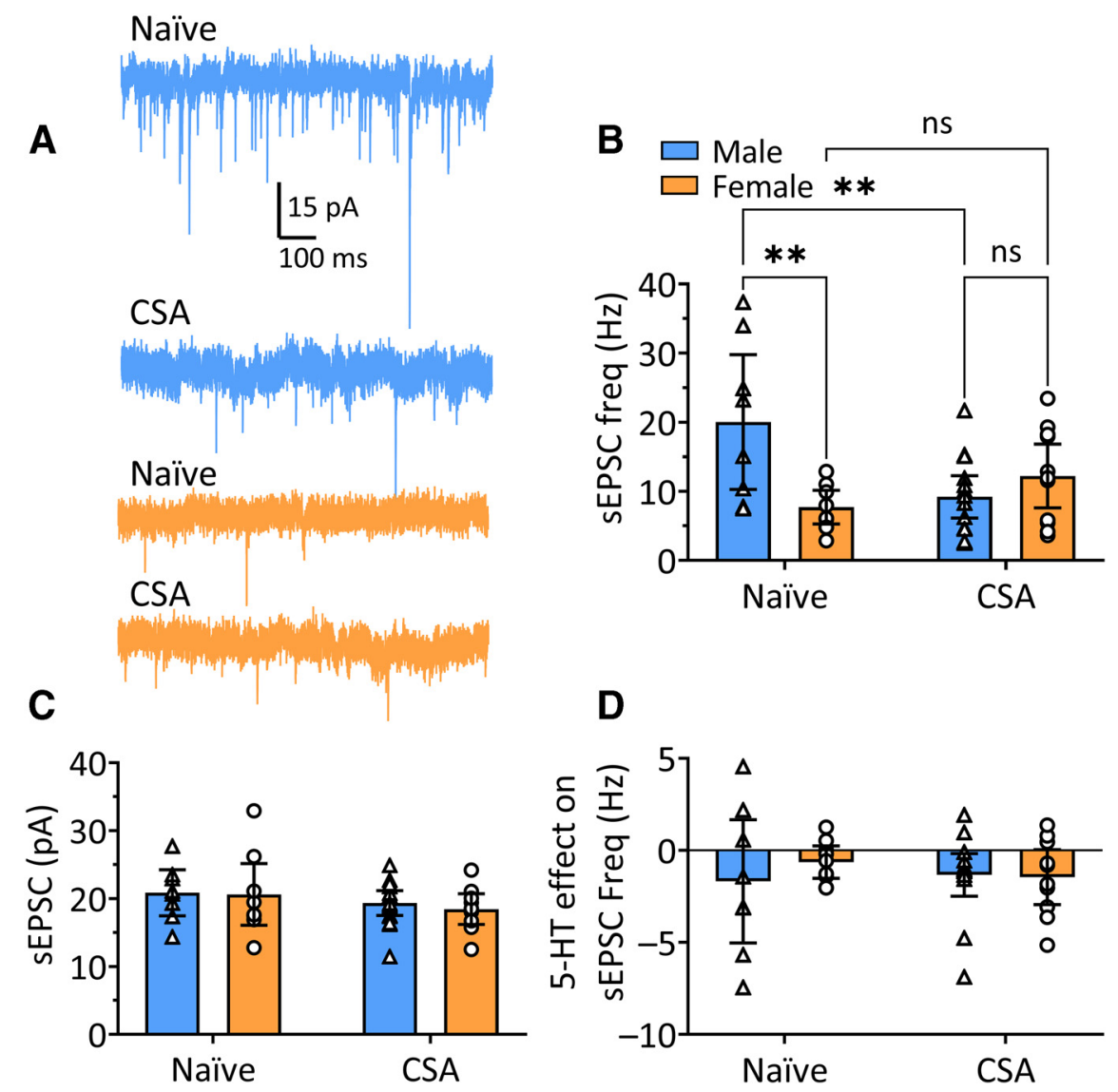

Figure 9. Properties of sEPSCs in OFC ${ }^{P V}$ interneurons following CSA and lack of effects of 5-HT in Pvalb-iCre rats. $\boldsymbol{A}$, Representative traces showing SEPSCs from male (blue traces) and female (orange traces) OFC ${ }^{\mathrm{PV}}$ cells from naive rats and those withdrawn from CSA. $\boldsymbol{B}$, Mean $( \pm 95 \% \mathrm{Cl})$ sEPSC frequency in OFC ${ }^{\mathrm{PV}}$ cells from male and female naive rats and those withdrawn from CSA. There was a significant reduction in SEPSC frequency in male OFC ${ }^{P V}$ cells following CSA (two-way ANOVA, sex $\times$ treatment interaction, $F_{(1,39)}=12.05, p<0.0013$, main effect sex, $F_{(1,39)}=4.434, p=0.0417$, treatment main effect, $F_{(1,39)}=2.057$, $p=0.160$; Tukey's post hoc test male naive vs male CSA, $p=0.006)$, and naive female rats exhibited a significantly lower frequency of sEPSCs compared with naive males $\left(p=0.005\right.$, Tukey's). ${ }^{\star \star} p<0.01$, Tukey's post-hoc test. Legend applies to $\boldsymbol{C}, \boldsymbol{D}$. $\boldsymbol{C}$, Mean $( \pm 95 \% \mathrm{Cl})$ sEPSC amplitude in OFC ${ }^{\mathrm{PV}}$ cells from male and female naive rats and those withdrawn from CSA. No changes in sEPSC amplitude were observed (two-way ANOVA, sex $\times$ treatment interaction, $\left.F_{(1,38)}=0.064, p=0.802\right)$. $\boldsymbol{D}$, Mean $( \pm 95 \% \mathrm{Cl}$ ) effect of 5 $\mathrm{HT}(20 \mu \mathrm{M})$ on sEPSC frequency in OFC ${ }^{\mathrm{PV}}$ cells from male and female naive Pvalb-iCre rats and those withdrawn from CSA. There was no effect of $5-\mathrm{HT}$ on OFC ${ }^{\mathrm{PV}}$ cells from naive or CSA-withdrawn rats (two-way ANOVA, sex $\times$ treatment interaction, $F_{(1,38)}=$ $0.582, p=0.450)$. ns, not significant.

Consistent with prior studies of PFC parvalbumin interneurons (Weber and Andrade, 2010; Athilingam et al., 2017), we found that 5-HT application caused depolarizing inward currents in the majority of OFC ${ }^{P V}$ cells in male and female Pvalb-iCre rats. However, this was blocked by the $5-\mathrm{HT}_{2}$ receptor antagonist, ketanserin, in only females. The reason for this sex difference in ketanserin sensitivity in OFC ${ }^{P V}$ neurons is unknown. However, significantly greater binding of $\left[{ }^{3} \mathrm{H}\right]$-ketanserin to $5-\mathrm{HT}_{2} \mathrm{Rs}$ in all layers of the female rat hippocampus has been reported (Zhang et al., 1999), and this may be relevant in the female OFC. Alternatively, outward currents were observed in a minority of male $\mathrm{OFC}^{\mathrm{PV}}$ neurons during $5-\mathrm{HT}$ application in the present study (Fig. $5 \mathrm{C}$ ) that were similar to outward currents mediated by $5 \mathrm{HT}_{1 \mathrm{~A}}$ receptors in male rat PyNs (Wright et al., 2017). As this outward current may compete with the 5-HT-activated inward current, a partial blockade of inward current by ketanserin may be obscured.
Another possibility may arise from the observations that ketanserin has higher affinity for $5-\mathrm{HT}_{2 \mathrm{~A}}$ versus $5-\mathrm{HT}_{2 \mathrm{C}}$ receptors, and a low affinity for $5-\mathrm{HT}_{2 \mathrm{~B}}$ receptors (Barnes and Sharp, 1999). Therefore, sex-linked differences in the expression of these $5-\mathrm{HT}_{2} \mathrm{R}$ subtypes could result in insensitivity to ketanserin in the male OFC ${ }^{P V}$ cells. Finally, differences in $5-\mathrm{HT}_{2 \mathrm{~A}}$ versus $5-\mathrm{HT}_{2 \mathrm{C}}$ receptor expression on OFC ${ }^{P V}$ neurons between male and female rats have also been reported after methamphetamine self-administration (Hankosky et al., 2018), suggesting some sexlinked lability in the expression of $5-\mathrm{HT}_{2} \mathrm{R}$ subtypes in these neurons. In addition to these differences in cellular distribution of $5-\mathrm{HT}$ receptor subtypes, sexually dimorphic effects of $5-\mathrm{HT}_{2 \mathrm{C}} \mathrm{R}$ and $5-\mathrm{HT}_{1 \mathrm{~A}} \mathrm{R}$ activation on CSA have been reported in rhesus monkeys (Collins and France, 2018). Therefore, data from the present and prior studies support the idea that $5-\mathrm{HT}_{2} \mathrm{R}$ receptor subtype distribution differs between male and female mammals. 
Sex-related differences were also noted in membrane and synaptic properties of OFC ${ }^{P V}$ neurons from naive rats and from those withdrawn from CSA. Thus, OFC ${ }^{P V}$ cells in naive female rats exhibited lower sEPSC baseline frequencies than males, suggesting that there is a lower probability of glutamate release onto these neurons in females. However, in contrast to the prominent increase in glutamate release by 5-HT reported in OFC PyNs (Wright et al., 2017), this was unaffected by $5-\mathrm{HT}$ in OFC ${ }^{\mathrm{PV}}$ cells in naive rats and those withdrawn from CSA. Despite this, $\mathrm{OFC}^{\mathrm{PV}}$ cells in male Pvalb-iCre rats exhibited smaller holding currents, depolarized membrane potentials (Fig. $8 C, D$ ), and a reduction in sEPSCs following CSA (Fig. 9B). However, the inward currents caused by $5-\mathrm{HT}$ were unchanged by CSA in OFC ${ }^{P V}$ cells from males and females (Fig. 8G,H). Although the effects of $5-\mathrm{HT}$ on OFC ${ }^{P V}$ cells did not change after CSA withdrawal, the changes in $\mathrm{OFC}^{\mathrm{PV}}$ neuron properties that were observed in males are likely to have profound effects on cortical circuit function and its participation in behavior. These changes in male rats could be compensatory and lead to a greater resistance to cocaine addiction compared with females (Carroll and Anker, 2010), or perhaps to an increased vulnerability to relapse to cocaine seeking triggered by conditioned cues under certain conditions, as reported in male rats (Fuchs et al., 2005). Collectively, our data show that male $\mathrm{OFC}^{\mathrm{PV}}$ neurons are more sensitive to the effects of CSA itself, that 5-HT receptor subtypes may be differentially expressed on $\mathrm{OFC}^{\mathrm{PV}}$ neurons of males and females, and, unlike that reported in OFC PyNs (Wright et al., 2017), the effects of 5-HT on OFC ${ }^{P V}$ cells are unaltered after CSA withdrawal. Therefore, these results suggest that withdrawal from cocaine exposure disrupts $5-\mathrm{HT}$ signaling primarily at OFC PyNs, and that this may account for the dysregulated OFC-dependent behavioral and cognitive processes observed in CUD in humans and in animal models of cocaine addiction.

\section{References}

Athilingam JC, Ben-Shalom R, Keeshen CM, Sohal VS, Bender KJ (2017) Serotonin enhances excitability and gamma frequency temporal integration in mouse prefrontal fast-spiking interneurons. Elife 6:e31991.

Azmitia EC, Segal M (1978) An autoradiographic analysis of the differential ascending projections of the dorsal and median raphe nuclei in the rat. J Comp Neurol 179:641-667.

Barnes NM, Sharp T (1999) A review of central 5-HT receptors and their function. Neuropharmacology 38:1083-1152.

Bäck S, Necarsulmer J, Whitaker LR, Coke LM, Koivula P, Heathward EJ, Fortuno LV, Zhang Y, Yeh CG, Baldwin HA, Spencer MD, MejiasAponte CA, Pickel J, Hoffman AF, Spivak CE, Lupica CR, Underhill SM, Amara SG, Domanskyi A, Anttila JE, et al. (2019) Neuron-specific genome modification in the adult rat brain using CRISPR-Cas9 transgenic rats. Neuron 102:105-119.e8.

Bechara A (2005) Decision making, impulse control and loss of willpower to resist drugs: a neurocognitive perspective. Nat Neurosci 8:1458-1463.

Bissonette GB, Schoenbaum G, Roesch MR, Powell EM (2015) Interneurons are necessary for coordinated activity during reversal learning in orbitofrontal cortex. Biol Psychiatry 77:454-464.

Boulougouris V, Robbins TW (2010) Enhancement of spatial reversal learning by $5-\mathrm{HT} 2 \mathrm{C}$ receptor antagonism is neuroanatomically specific. J Neurosci 30:930-938.
Calu DJ, Stalnaker TA, Franz TM, Singh T, Shaham Y, Schoenbaum G (2007) Withdrawal from cocaine self-administration produces long-lasting deficits in orbitofrontal-dependent reversal learning in rats. Learn Mem 14:325-328.

Carroll ME, Anker JJ (2010) Sex differences and ovarian hormones in animal models of drug dependence. Horm Behav 58:44-56.

Chandler DJ, Lamperski CS, Waterhouse BD (2013) Identification and distribution of projections from monoaminergic and cholinergic nuclei to functionally differentiated subregions of prefrontal cortex. Brain Res 1522:38-58.

Clarke HF, Dalley JW, Crofts HS, Robbins TW, Roberts AC (2004) Cognitive inflexibility after prefrontal serotonin depletion. Science 304:878-880.

Collins GT, France CP (2018) Effects of lorcaserin and buspirone, administered alone and as a mixture, on cocaine self-administration in male and female rhesus monkeys. Exp Clin Psychopharmacol 26:488-496.

Dalley JW, Cardinal RN, Robbins TW (2004) Prefrontal executive and cognitive functions in rodents: neural and neurochemical substrates. Neurosci Biobehav Rev 28:771-784.

Filipiak WE, Saunders TL (2006) Advances in transgenic rat production. Transgenic Res 15:673-686.

Fuchs RA, Evans KA, Mehta RH, Case JM, See RE (2005) Influence of sex and estrous cyclicity on conditioned cue-induced reinstatement of cocaine-seeking behavior in rats. Psychopharmacology (Berl) 179:662-672.

Furr A, Danet Lapiz-Bluhm M, Morilak DA (2012) 5-HT2A receptors in the orbitofrontal cortex facilitate reversal learning and contribute to the beneficial cognitive effects of chronic citalopram treatment in rats. Int J Neuropsychopharm 15:1295-1305.

Gallagher M, McMahan RW, Schoenbaum G (1999) Orbitofrontal cortex and representation of incentive value in associative learning. J Neurosci 19:6610-6614.

Gonçalves L, Nogueira MI, Shammah-Lagnado SJ, Metzger M (2009) Prefrontal afferents to the dorsal raphe nucleus in the rat. Brain Res Bull 78:240-247.

Gremel CM, Costa RM (2013) Orbitofrontal and striatal circuits dynamically encode the shift between goal-directed and habitual actions. Nat Commun 4:2264.

Hankosky ER, Westbrook SR, Haake RM, Willing J, Raetzman LT, Juraska JM, Gulley JM (2018) Age- and sex-dependent effects of methamphetamine on cognitive flexibility and 5-HT2C receptor localization in the orbitofrontal cortex of Sprague-Dawley rats. Behav Brain Res 349:16-24.

Hardung S, Epple R, Jäckel Z, Eriksson D, Uran C, Senn V, Gibor L, Yizhar O, Diester I (2017) A functional gradient in the rodent prefrontal cortex supports behavioral inhibition. Curr Biol 27:549-555.

Hoover WB, Vertes RP (2011) Projections of the medial orbital and ventral orbital cortex in the rat. J Comp Neurol 519:3766-3801.

Hornung JP, Fritschy JM, Törk I (1990) Distribution of two morphologically distinct subsets of serotoninergic axons in the cerebral cortex of the marmoset. J Comp Neurol 297:165-181.

Izquierdo A (2017) Functional heterogeneity within rat orbitofrontal cortex in reward learning and decision making. J Neurosci 37:10529-10540.

Izquierdo A, Murray EA (2004) Combined unilateral lesions of the amygdala and orbital prefrontal cortex impair affective processing in rhesus monkeys. J Neurophysiol 91:2023-2039.

Izquierdo A, Carlos K, Ostrander S, Rodriguez D, McCall-Craddolph A, Yagnik G, Zhou F (2012) Impaired reward learning and intact motivation after serotonin depletion in rats. Behav Brain Res 233:494-499.

Jentsch JD, Olausson P, De La Garza R 2nd, Taylor JR (2002) Impairments of reversal learning and response perseveration after repeated, intermittent cocaine administrations to monkeys. Neuropsychopharmacology 26:183-190.

Jones B, Mishkin M (1972) Limbic lesions and the problem of stimulus-reinforcement associations. Exp Neurol 36:362-377.

Koós T, Tepper JM (1999) Inhibitory control of neostriatal projection neurons by GABAergic interneurons. Nat Neurosci 2:467-472. 
Liu S, Bubar MJ, Lanfranco MF, Hillman GR, Cunningham KA (2007) Serotonin2C receptor localization in GABA neurons of the rat medial prefrontal cortex: implications for understanding the neurobiology of addiction. Neuroscience 146:1677-1688.

Lucantonio F, Stalnaker TA, Shaham Y, Niv Y, Schoenbaum G (2012) The impact of orbitofrontal dysfunction on cocaine addiction. Nat Neurosci 15:358-366.

Lucantonio F, Takahashi YK, Hoffman AF, Chang CY, BaliChaudhary S, Shaham Y, Lupica CR, Schoenbaum G (2014) Orbitofrontal activation restores insight lost after cocaine use. Nat Neurosci 17:1092-1099.

Man MS, Dalley JW, Roberts AC (2010) Opposing effects of 5,7-DHT infusions into the orbitofrontal cortex and amygdala on flexible responding. Cereb Cortex 20:1668-1675.

New AS, Buchsbaum MS, Hazlett EA, Goodman M, Koenigsberg HW, Lo J, Iskander L, Newmark R, Brand J, O'Flynn K, Siever LJ (2004) Fluoxetine increases relative metabolic rate in prefrontal cortex in impulsive aggression. Psychopharmacology (Berl) 176:451-458.

Nonkes LJ, Maes JH, Homberg JR (2013) Improved cognitive flexibility in serotonin transporter knockout rats is unchanged following chronic cocaine self-administration. Addict Biol 18:434-440.

Ostlund SB, Balleine BW (2007) Orbitofrontal cortex mediates outcome encoding in Pavlovian but not instrumental conditioning. $\mathrm{J}$ Neurosci 27:4819-4825.

Paxinos G, Watson C (1998) The Rat Brain in Stereotaxic Coordinates, Ed 4. San Diego.:Academic Press.

Puig MV, Watakabe A, Ushimaru M, Yamamori T, Kawaguchi Y (2010) Serotonin modulates fast-spiking interneuron and synchronous activity in the rat prefrontal cortex through 5-HT1A and 5HT2A receptors. J Neurosci 30:2211-2222.

Roberts AC (2011) The importance of serotonin for orbitofrontal function. Biol Psychiatry 69:1185-1191.

Santana N, Bortolozzi A, Serrats J, Mengod G, Artigas F (2004) Expression of serotonin1 $A$ and serotonin2A receptors in pyramidal and GABAergic neurons of the rat prefrontal cortex. Cereb Cortex 14:1100-1109.

Saxena S, Brody AL, Maidment KM, Dunkin JJ, Colgan M, Alborzian S, Phelps ME, Baxter LR Jr (1999) Localized orbitofrontal and subcortical metabolic changes and predictors of response to paroxetine treatment in obsessive-compulsive disorder. Neuropsychopharmacology 21:683-693.

Schoenbaum G, Esber GR (2010) How do you (estimate you will) like them apples? Integration as a defining trait of orbitofrontal function. Curr Opin Neurobiol 20:205-211.

Schoenbaum G, Setlow B (2005) Cocaine makes actions insensitive to outcomes but not extinction: implications for altered orbitofrontal-amygdalar function. Cereb Cortex 15:1162-1169.

Schoenbaum G, Shaham Y (2008) The role of orbitofrontal cortex in drug addiction: a review of preclinical studies. Biol Psychiatry 63:256-262.

Schoenbaum G, Chiba AA, Gallagher M (1998) Orbitofrontal cortex and basolateral amygdala encode expected outcomes during learning. Nat Neurosci 1:155-159.

Schoenbaum G, Saddoris MP, Ramus SJ, Shaham Y, Setlow B (2004) Cocaine-experienced rats exhibit learning deficits in a task sensitive to orbitofrontal cortex lesions. Eur J Neurosci 19:19972002.

Schoenbaum G, Chang CY, Lucantonio F, Takahashi YK (2016) Thinking outside the box: orbitofrontal cortex, imagination, and how we can treat addiction. Neuropsychopharmacology 41:29662976.

Shimshek DR, Kim J, Hübner MR, Spergel DJ, Buchholz F, Casanova E, Stewart AF, Seeburg PH, Sprengel R (2002) Codonimproved Cre recombinase (iCre) expression in the mouse. Genesis 32:19-26.

Simmler LD, Anacker A, Levin MH, Vaswani NM, Gresch PJ, Nackenoff AG, Anastasio NC, Stutz SJ, Cunningham KA, Wang J, Zhang B, Henry LK, Stewart A, Veenstra-VanderWeele J, Blakely RD (2017) Blockade of the 5-HT transporter contributes to the behavioural, neuronal and molecular effects of cocaine. $\mathrm{Br} J$ Pharmacol 174:2716-2738.

Takahashi YK, Chang CY, Lucantonio F, Haney RZ, Berg BA, Yau HJ, Bonci A, Schoenbaum G (2013) Neural estimates of imagined outcomes in the orbitofrontal cortex drive behavior and learning. Neuron 80:507-518.

Tischer BK, Smith GA, Osterrieder N (2010) En passant mutagenesis: a two step markerless red recombination system. Methods Mole Biol 634:421-430.

Torres GE, Gainetdinov RR, Caron MG (2003) Plasma membrane monoamine transporters: structure, regulation and function. Nat Rev Neurosci 4:13-25.

Tremblay L, Schultz W (1999) Relative reward preference in primate orbitofrontal cortex. Nature 398:704-708.

Vázquez-Borsetti P, Cortés R, Artigas F (2009) Pyramidal neurons in rat prefrontal cortex projecting to ventral tegmental area and dorsal raphe nucleus express 5-HT2A receptors. Cereb Cortex 19:1678-1686.

Volkow ND, Fowler JS (2000) Addiction, a disease of compulsion and drive: involvement of the orbitofrontal cortex. Cereb Cortex 10:318-325.

Volkow ND, Fowler JS, Wang GJ, Hitzemann R, Logan J, Schlyer DJ, Dewey SL, Wolf AP (1993) Decreased dopamine D2 receptor availability is associated with reduced frontal metabolism in cocaine abusers. Synapse 14:169-177.

Weber ET, Andrade R (2010) Htr2a Gene and 5-HT(2A) Receptor Expression in the Cerebral Cortex Studied Using Genetically Modified Mice. Front Neurosci 4:36.

West EA, Forcelli PA, McCue DL, Malkova L (2013) Differential effects of serotonin-specific and excitotoxic lesions of OFC on conditioned reinforcer devaluation and extinction in rats. Behav Brain Res 246:10-14.

Wilson MA, Molliver ME (1991a) The organization of serotonergic projections to cerebral cortex in primates: regional distribution of axon terminals. Neuroscience 44:537-553.

Wilson MA, Molliver ME (1991b) The organization of serotonergic projections to cerebral cortex in primates: retrograde transport studies. Neuroscience 44:555-570.

Witten IB, Steinberg EE, Lee SY, Davidson TJ, Zalocusky KA, Brodsky M, Yizhar O, Cho SL, Gong S, Ramakrishnan C, Stuber GD, Tye KM, Janak PH, Deisseroth K (2011) Recombinase-driver rat lines: tools, techniques, and optogenetic application to dopamine-mediated reinforcement. Neuron 72:721-733.

Wright AM, Zapata A, Baumann MH, Elmore JS, Hoffman AF, Lupica CR (2017) Enduring loss of serotonergic control of orbitofrontal cortex function following contingent and noncontingent cocaine exposure. Cereb Cortex 27:5463-5476.

Zhang L, Ma W, Barker JL, Rubinow DR (1999) Sex differences in expression of serotonin receptors (subtypes $1 \mathrm{~A}$ and $2 \mathrm{~A}$ ) in rat brain: a possible role of testosterone. Neuroscience 94:251-259. 